\title{
LOS MOTIVOS VISUALES EN EL CINE DE INGMAR BERGMAN
}

\author{
Diana González Martín
}

\section{RESUMEN}

La obra fílmica de Ingmar Bergman se caracteriza especialmente por la maestría con que el cineasta sueco ha recurrido al uso de diferentes motivos visuales, es decir, aquellos conceptos simbólicos plasmados en imágenes que se repiten en una constante, capaces de contener todo ese compendio de reflexiones que define el genio creativo de cualquier artista. Por tanto, se puede hablar con certeza de la existencia de la iconografía cinematográfica, que, aunque se origina a raíz de las fuentes iconográficas pictóricas, también desarrolla sus propios motivos. El presente artículo tiene como objetivo el estudio, la identificación y el análisis de los motivos visuales más representativos en las películas de Ingmar Bergman: el espejo, el erotismo y la muerte. A través de estos, es posible comprender cómo Bergman concebía ideas como el amor, el sexo, la mujer, la familia, el mundo de las apariencias, la sociedad posmoderna y la trascendencia de la vida y la incertidumbre sobre la existencia de Dios.

Palabras Clave: cine, cine de autor, Ingmar Bergman, motivo visual, simbolismo, iconografía.

\section{VISUAL MOTIFS IN INGMAR BERMAN'S CINEMA}

\section{Abstract}

Ingmar Bergman's film work is characterized by the mastery of the use of different visual motifs, that is to say, the symbolic concepts expressed in the images, continually repeated and capable to contain all the reflections which define the creative genius of the artist. Therefore, we can certainly speak about the existence of cinematographic iconography that, although it originates from the pictorial iconographic sources, also develops its own motives. The objective of this article is the study, the identification and the analysis of the most representative visual motifs in Ingmar Bergman's films: the mirror, the eroticism, and the death. Through these symbols, we can understand how Bergman conceived the ideas of love, sex, woman, family, the world of appearances, postmodern society, the transcendence of life and the uncertainty about the existence of God.

KEYWORDS: cinema, author cinema, Ingmar Bergman, visual motif, symbolism, iconography. 


\section{INTRODUCCIÓN}

Las primeras imágenes mentales que evoca el espectador de la obra cinematográfica de Ingmar Bergman las suele relacionar con lo misterioso, lo pintoresco, lo decadente o, incluso, lo irreverente. Danzas de máscaras grotescas; secuencias oníricas que parecen estar sacadas de visiones surrealistas; el color rojo intenso en paredes, vestidos y objetos; mujeres que, desnudas ante la cámara, más que sensualidad lo que dejan al descubierto es su alma; escenas de violación, masturbación e incesto; pastores y creyentes que cuestionan su fe; solitarios cuya soledad les pesa o a suicidas que les cuesta dar el paso y apretar el gatillo de su pistola; silencios prolongados que resuenan con más fuerza que cualquier ruido insoportable y miradas que hablan; viajes en los que se rememora con nostalgia el pasado; playas deshabitadas convertidas en paraíso terrenal para los amantes; erotismo a través de gestos y simples movimientos; cuerpos que se retuercen de dolor antes de exhalar el último suspiro; la espléndida luz del verano nórdico y el humo de los ferrocarriles y cigarrillos a medio apagar; valses vieneses, jazz y Sarabande en D menor de Johann Sebastian Bach; espejos, muñecas, marionetas, payasos y saltimbanquis; teatros, cabaret y cine dentro de cine; parejas y familias destinadas a no comprenderse; escenas de crueldad y esperanza, de miedos y anhelos. En cualquier caso, el lirismo, el misticismo y la gravedad con que se describen las películas de Bergman confunden profundamente al espectador, quien es capaz de intuir que en ellas se esconde un significado oculto.

Hay que tener en cuenta que el cine, además de ser un arte visual y contemplativo, también es un arte del relato, y Bergman es un artista a la vieja usanza: es un artesano de imágenes. Las elabora y transforma cuidadosamente hasta convertirlas en historias, ideas y reflexiones cuyas significaciones no se presentan de manera sencilla y directa sino que otorgan al espectador el relevante papel de desentrañarlas y así comprenderlas. Por tanto, las imágenes tienen la capacidad de contar, enriqueciendo de esta manera la estructura técnica del guion, de filmación y de contenido estético. Al mismo tiempo, cuentan con un sentido narrativo y un valor simbólico que trascienden más allá de la simple descripción.

Para comprender la trayectoria cinematográfica de Bergman es importante profundizar en su biografía, especialmente la que el propio Bergman relata en sus memorias -destacando Linterna mágica (1988) e Imágenes (1992) ${ }^{1}$. Al igual que otros grandes autores del cine moderno de la talla de Truffaut o Fellini, Bergman convierte sus experiencias en anécdotas y sus reflexiones en material fundamental para sus películas y obras teatrales. Mandelbaum en Cahiers de Cinema (2007) considera que Bergman «también apuesta por la confusión en la deliberada elaboración de su propio mito» ${ }^{2}$. Por consiguiente, estamos ante una autobiografía en la

${ }^{1}$ Bergman, I. (1988): Linterna mágica, Barcelona, Tusquets Editores. Bergman, I. (1992): Imágenes, Barcelona, Tusquets Editores, 1992.

2 Mandelbaum, J. (2007): Cahiers du cinema. Colección de grandes directores. El libro de Ingmar Bergman, Madrid, Edición particular para el periódico El País, p. 12. 


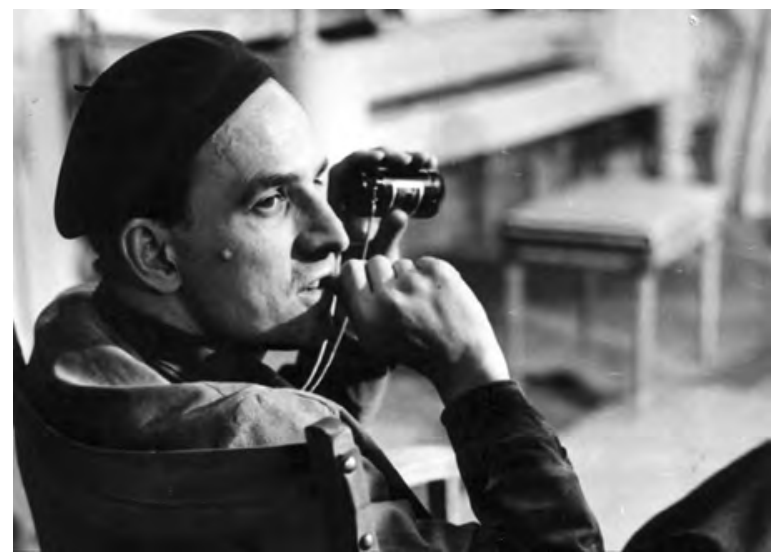

Bergman durante un rodaje.

Fuente: Stiftelsen Ingmar Bergman (http://www.ingmarbergman.se).

que cuesta discernir entre lo real y lo ficticio. Se desarrolla, por lo tanto, una lectura metatextual que sin duda aparece reflejada en sus producciones. La finalidad de Bergman al construir sus memorias añadiendo discursos fantasiosos y novelescos se basa en que, a partir de estos, se trace un camino que lleve a la verdad más intrínseca y pura, la cual en cierto modo se define como dolorosa a ojos del cineasta ${ }^{3}$.

Este sentimiento se puede comprender si sabemos primero cómo concibe Bergman la realidad en sus películas; una que es cruda y carente de esperanza para sus atormentados personajes, los cuales se amparan en el abrazo de lo irreal, la superficialidad, lo religioso o lo metafísico para poder seguir adelante con sus vidas. Robin Wood en su libro Ingmar Bergman (1972) afirma que, mientras que los personajes de las películas de Michelangelo Antonioni «están siempre destinados a una derrota definitiva y parecen aceptarla con cierta complacencia», ocurre todo lo contrario con los de Bergman, que "partiendo de la enfermedad y la prisión, sus personajes intentan, a veces en vano, pero siempre apasionadamente, conquistar el reino de la salud y la libertad ${ }^{5} »$. Esta intencionalidad de Bergman de

${ }_{3}^{3}$ Bergman describe esta idea en Imágenes (1992): «Me di cuenta, firme y brutalmente, de que había concebido la mayoría de las películas en las entrañas del alma, corazón, cerebro, nervios, órganos genitales y sobre todo en las tripas. Un deseo que no tiene nombre las sacó a la luz», p. 17.

${ }^{4}$ En su libro Para mí, hacer una película es vivir (2002) comenta que «siente admiración por la cinematografía de Bergman porque se centraba del mismo modo que él en los individuos», pero apuntando que ambos se diferenciaban a la hora de «representar las formas y figuras de estilo». Antonioni, M. (2002): Para mi, hacer una pelicula es vivir, Madrid, Grupo Planeta (GBS), p. 218.

5 Wood, R. (1972): Ingmar Bergman, Madrid, Editorial Fundamentos, p. 15. 
querer transformar su biografía en un relato con tintes ficticios es explicada por el francés Philippe Lejeune, profesor, ensayista y especialista en autobiografía, en su libro El pacto autobiográfico y otros estudios (1994). Para Lejeune, esa faceta del relato íntimo de cuestionable veracidad con que se describe el cine autobiográfico en relación con Bergman y a todos aquellos autores del cine moderno, apunta que está condenado a la ficción.

La autobiografía es necesariamente «una ficción producida en circunstancias especiales, pero que sin una base sincera en el hecho referencial la autobiografía corre el riesgo de perder su estatus como género diferenciado y de confundirse completamente con la ficción ${ }^{6} »$. Estamos, pues, ante un cine autobiográfico en donde Bergman juega con la autoficción y el cine especular.

\section{EL MOTIVO VISUAL}

Roberto Rossellini afirma en su libro El cine revelado (2000) que «lo importante son las ideas, no las imágenes; basta con tener ideas muy claras y es fácil encontrar la imagen más directa para expresar la idea ${ }^{7}$. Rossellini, sobresaliendo por su genialidad artística, supo aplicar esta sentencia en sus películas: toda aquella representación artística debe encerrar una idea mediante la cual se pueda expresar sentimientos, emociones o ideologías. Y es que el arte ha tenido siempre como función la de contenedor de ideas, desde las pinturas rupestres del Paleolítico hasta las nuevas propuestas del arte contemporáneo. Como explica Sixto J. Castro en En teoría, es arte: una introducción a la estética (2005), "el creador de una obra de arte puede pensar en el público de su época, pero el ser verdadero de su obra es aquello que ella es capaz de decir, y esto sobrepasa por principio toda limitación histórica» ${ }^{8}$. Para llevar esto a la praxis, los artistas utilizan, a veces de manera muy deliberada, uno de los elementos visuales más importantes que expresan esas ideas contenidas en las obras de arte y que los diferencia del resto de autores al mismo tiempo. A este elemento visual se le denomina «motivo». En la RAE, el motivo es definido como un «rasgo característico que se repite en una obra o en un conjunto de ellas ${ }^{9}$ ». En este sentido, el motivo se puede entender como un fragmento extraído de la realidad -un objeto, por ejemplo- que el artista escogió ya no solo con una finalidad puramente mimética o estética.

El motivo debe contener ideas específicas que el propio artista extrae de sus tropismos más personales. Podemos comparar la definición de motivo con las mion, p. 20.

${ }^{6}$ Lejeune, P. (1994): El pacto autobiográfico y otros estudios, Madrid, Megazul-Endy-

7 Rosellini, R. (2000): El cine revelado, Barcelona, Paidós, p. 64.

${ }^{8}$ Castro, S.J. (2005): En teoría, es arte: una introducción a la estética, Madrid, Editorial San Esteban, p. 226.

9 Real Academia Española, RAE (2014): Diccionario de la lengua española, Versión online, consultada el 2 de julio de 2018: https://dle.rae.es/?id=PwDYZFz. 
«impresiones» descritas en El tiempo recobrado (1927) de Marcel Proust. Las impresiones contienen una parte meramente visual, pero cuentan además con una lectura simbólica, interpretativa, creada por el artista:

No me paré a pensar en la gran diferencia que existe entre la verdadera impresión que hemos tenido de una cosa y la impresión ficticia que nos damos cuando intentamos voluntariamente representárnosla ${ }^{10}$.

El motivo surgió a partir del nacimiento de la pintura, pero comenzó a desarrollarse plenamente cuando los artistas pudieron liberarse de las reglas impuestas por talleres y mecenazgos, usando a partir de entonces el motivo como un elemento con que definir su estilo. El abismo, por ejemplo, fue un motivo recurrente en el período romántico, pero que aún sigue estando vigente en la actualidad, especialmente en el mundo del cine.

Una de las obras más célebres que emplea este motivo es El caminante sobre el mar de nubes (Der Wanderer über dem Nebelmeer, 1818) de Caspar David Friedrich, que establece las pautas figurativas del motivo: el caminante que está de espaldas y con la mirada puesta hacia el horizonte, empequeñecido ante la inmensidad del paisaje que lo rodea. El abismo representa a grandes rasgos las dificultades que encuentra el hombre para llegar a sus aspiraciones. Asimismo, alude al tema del vacio y lo que este simboliza: la soledad, la muerte, el mundo del inconsciente, lo inescrutable, los miedos y las debilidades de quien lo observa.

No es de extrañar que este motivo sea imitado constantemente en los carteles estereotipados de las películas de acción y ciencia ficción actuales: el protagonista heroico que, mostrándose de espaldas, contempla un mundo que está sumido en el caos o lo estará pronto, y en el que intervendrá previsiblemente a favor del Bien.

En el campo de la cinematografía, lo más correcto sería denominar al motivo como «motivo visual» para diferenciarlo del «motivo pictórico», referido al campo de la pintura. Ya sean pictóricos o visuales, prácticamente se repiten los mismos motivos: el abismo, el espejo, la ventana, la sombra, el reloj..., entre otros. A partir de estos, se llega a ideas y conceptos más complejos. Los autores Balló y Bergala en Motivos visuales del cine (2016) comentan que los motivos visuales «funcionan como una disposición visual en la que el espectador puede encontrar emocionalmente, aunque no los conozca, algo de origen pictórico ${ }^{11}{ }^{\prime}$. Los motivos visuales aparecen colocados en diferentes planos, en las escenas, en los personajes o en torno a estos, en el atrezzo, etcétera. Es decir que, aunque el espectador carezca de un amplio bagaje pictórico, es capaz de discernir y leer el mensaje que estos motivos visuales representan. No todos los abismos, espejos, ventanas, sombras u otros elementos que aparezcan en el cine son motivos visuales al igual que ocurre con los motivos pictóricos. Aquellos elementos visuales que carecen de valor simbólico se denominan «imáge-

${ }_{10}$ Proust, M. (2011): El tiempo recobrado, Madrid, Editorial Alianza, p. 111.

11 Balló, J. y Bergala, A. (eds.) (2016): Motivos visuales del cine, Barcelona, Galaxia Gutenberg, p. 12. 


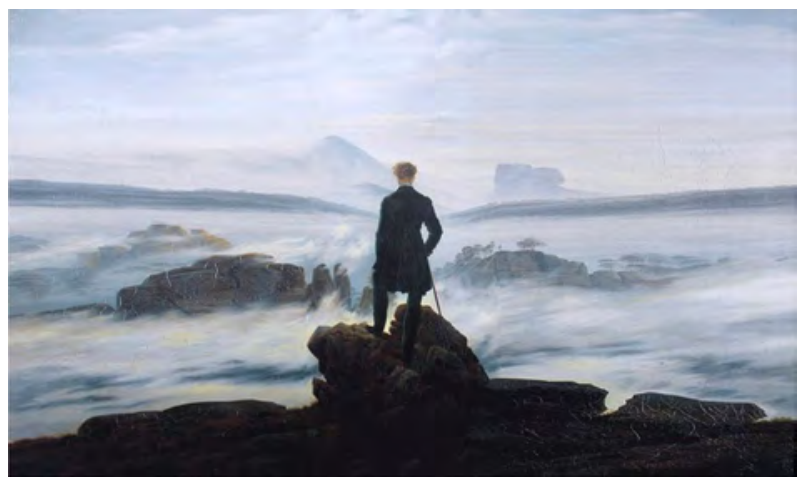

El caminante sobre el mar de nubes (1818) de Caspar David Friedrich (Fuente: Wikimedia Commons).
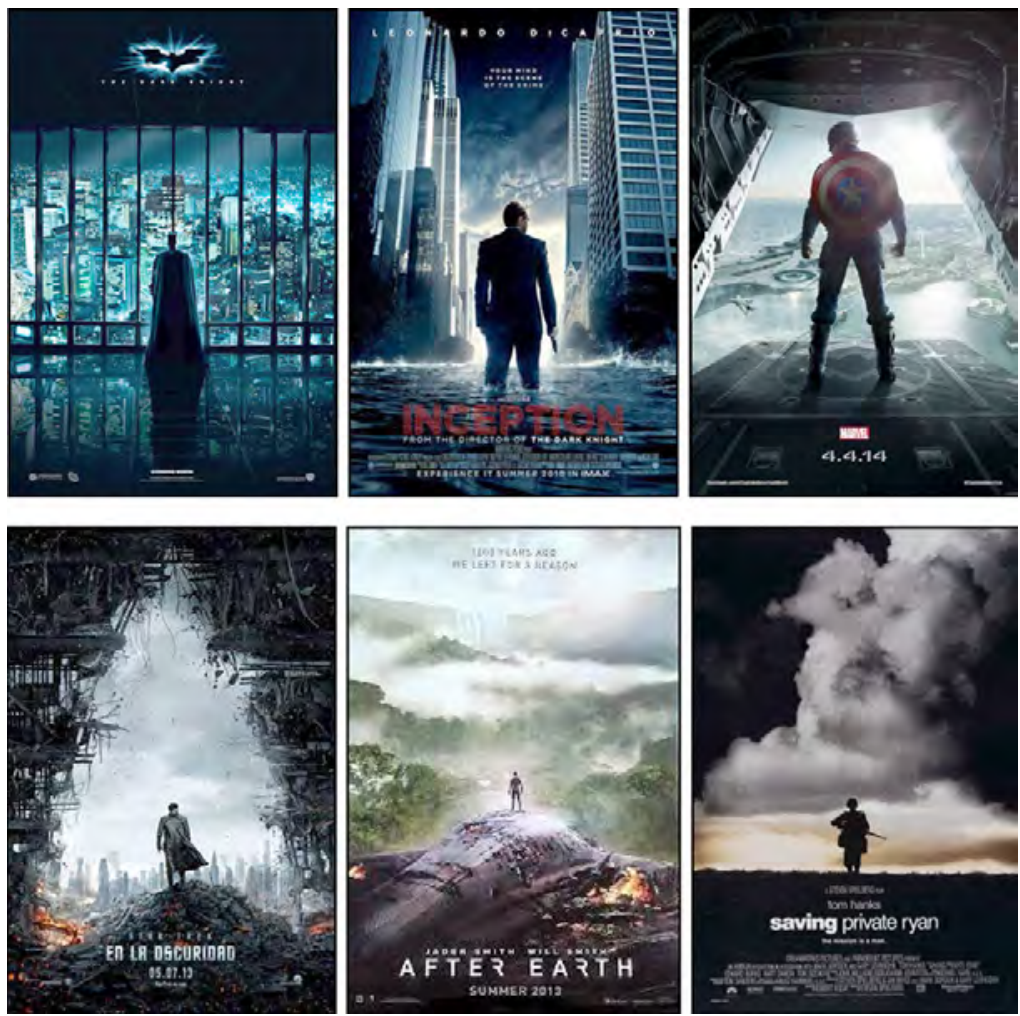

Ejemplos de carteles de films que imitan el motivo visual del abismo creado por Friedrich (de izquierda a derecha y de arriba abajo): El caballero oscuro (2008); Origen (2010); Capitán América: el soldado de invierno (2014); Star Trek: en la oscuridad (2013); After Earth (2013); y Salvar al soldado Ryan (1998). (Fuente: Filmaffinity). 
nes». Balló y Bergala comentan que «un motivo visual no es aquel que el cineasta no lo trabaja y no lo constituye como tal, y no ejerce una atracción creativa visible del tratamiento que hace de él ${ }^{12}{ }_{\eta}$. En consecuencia, hay que conocer primeramente la vida y obra del autor para comprender los motivos visuales que emplea de manera reiterada y rayando casi la obsesión. Estos pasan a ser necesarios en su acto de creación artística. El pintor David Hockney ${ }^{13}$ convirtió la piscina en el motivo principal de sus obras, que hasta entonces no se había dado en el mundo del arte; Giorgio Morandi ${ }^{14}$ optó por representar bodegones de botellas y otros recipientes de cristal; Balthus ${ }^{15}$ no se cansó de pintar y fotografiar lolitas recostadas en sofás y sillas; y Cézanne pintó constantemente la montaña de Sainte-Victoire, situada en el sur de Francia. En el mundo del cine también vemos cómo pasa el motivo visual a ser un elemento recurrente que finalmente adquiere un significado esencial y define la filmografía de sus cineastas: las manos en Robert Bresson; los insectos en Luis Buñuel; los caminos terrosos y solitarios en Abbás Kiarostami ${ }^{16}$; o los lagos en Kenji Mizogu$\mathrm{chi}^{17}$. Sin embargo, al igual que ocurre en pintura, hay motivos visuales que son de carácter universal. Se emplean bajo una misma significación simbólica por diferentes autores, de diferentes tendencias y épocas, tal y como ocurre en pintura. Un ejemplo de esto lo tenemos en la interpretación del abismo ya comentada anteriormente.

Estamos, pues, ante un motivo visual que es dinámico, que se adapta a los deseos creativos, poéticos e ideológicos de los cineastas, pero que del mismo modo es capaz de contener significaciones generalizadas que se mantienen a lo largo de la Historia del Cine.

12 Ibid., p. 14.

${ }^{13}$ David Hockney (9 de julio de 1937) es un pintor, escenógrafo y fotógrafo británico relacionado con las corrientes del arte pop y del hiperrealismo.

${ }^{14}$ Giorgio Morandi (1890-1964) fue un pintor italiano cuya obra está dedicada prácticamente al género del bodegón.

${ }_{15}$ Balthasar Klossowski de Rola (1908-2001) fue un artista de origen polaco-francés. Su obra pictórica, sensualista y erótica, no se salvó de ser perseguida por la censura.

${ }^{16}$ Abbás Kiarostami (22 de junio de 1949) es un cineasta, guionista y fotógrafo de origen iraní reconocido a nivel internacional.

${ }^{17}$ Kenji Mizoguchi (1898-1953) fue uno de los cineastas más representativos del cine clásico japonés, junto con Akira Kurosawa y Yasujirō Ozu. 

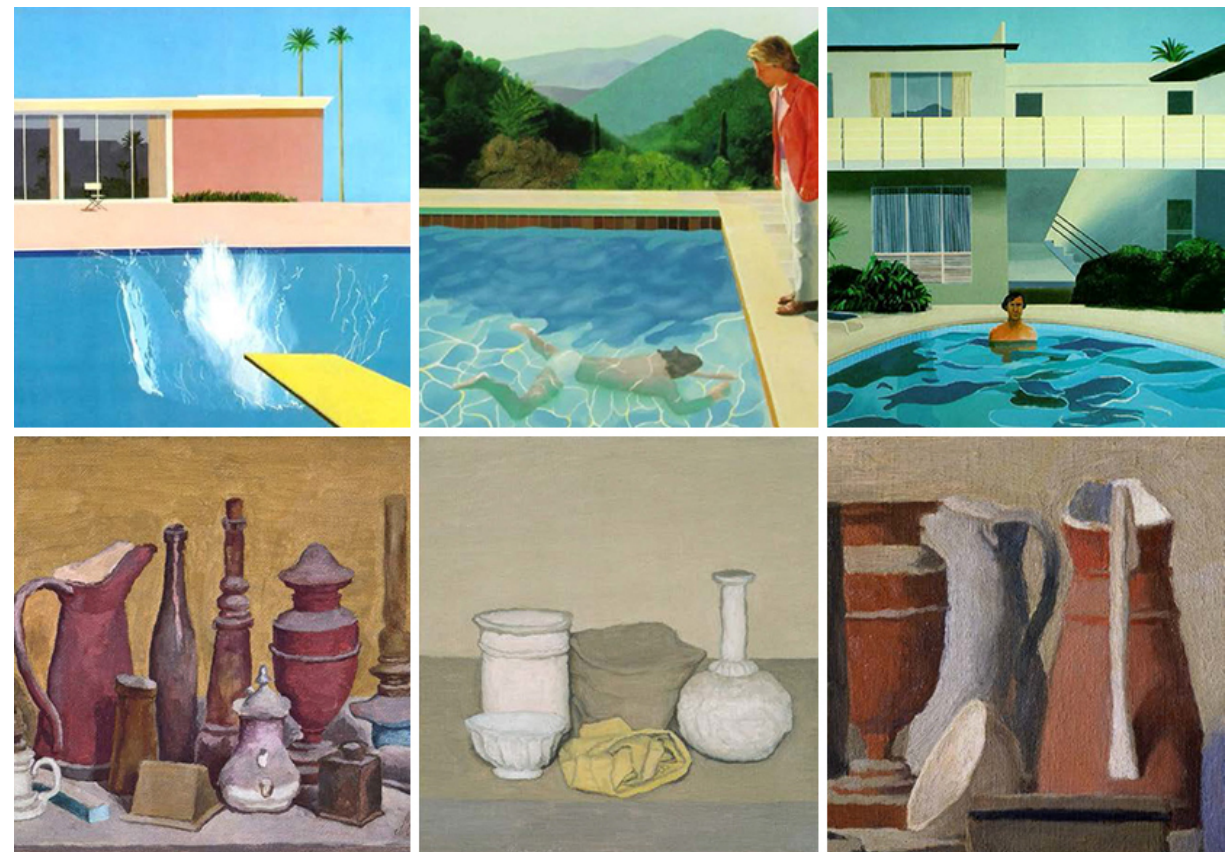

$\stackrel{\circ}{\circ}$
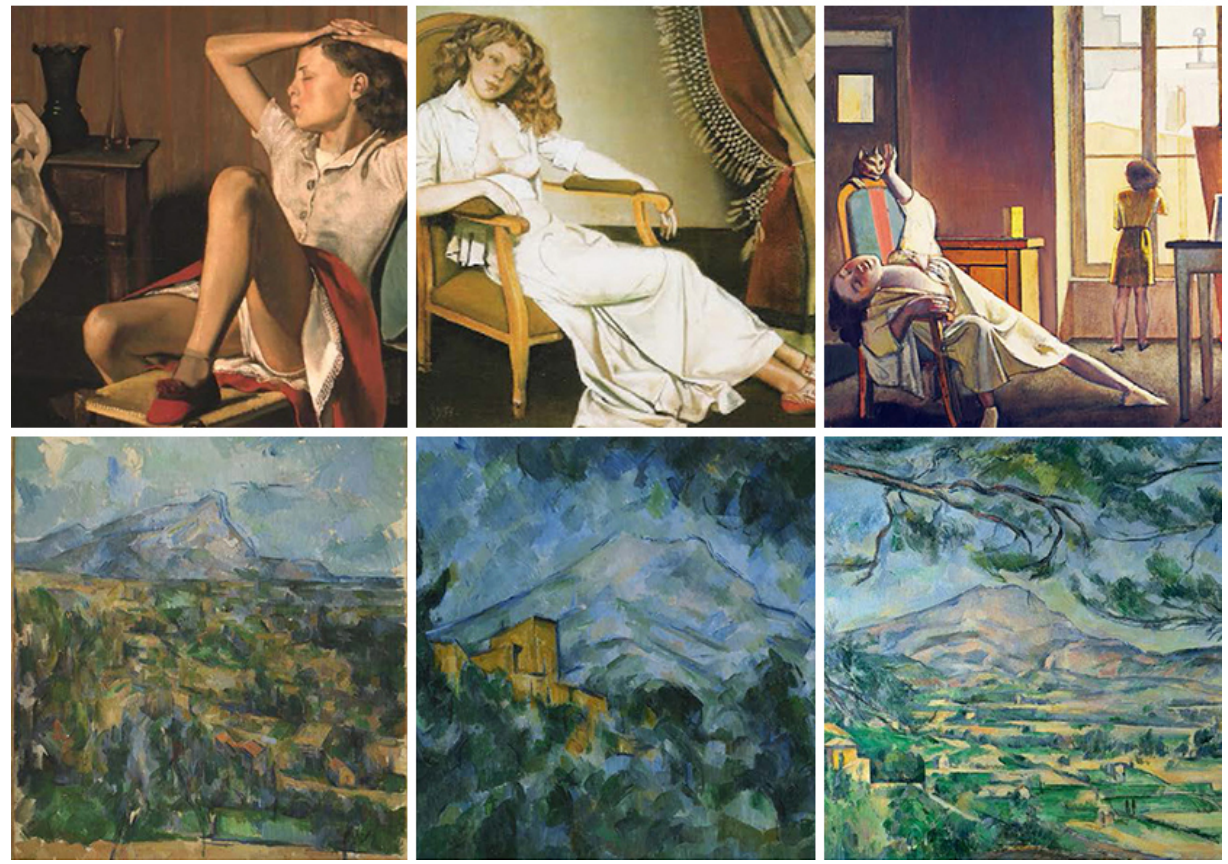

Motivos pictóricos. Primera fila, la piscina en Hockney; segunda fila, los bodegones de botellas en Morandi; tercera fila, las jóvenes recostadas en Balthus; y cuarta fila, la montaña de Sainte-Victorie en Cézanne. (Fuente: Wikimedia Commons). 

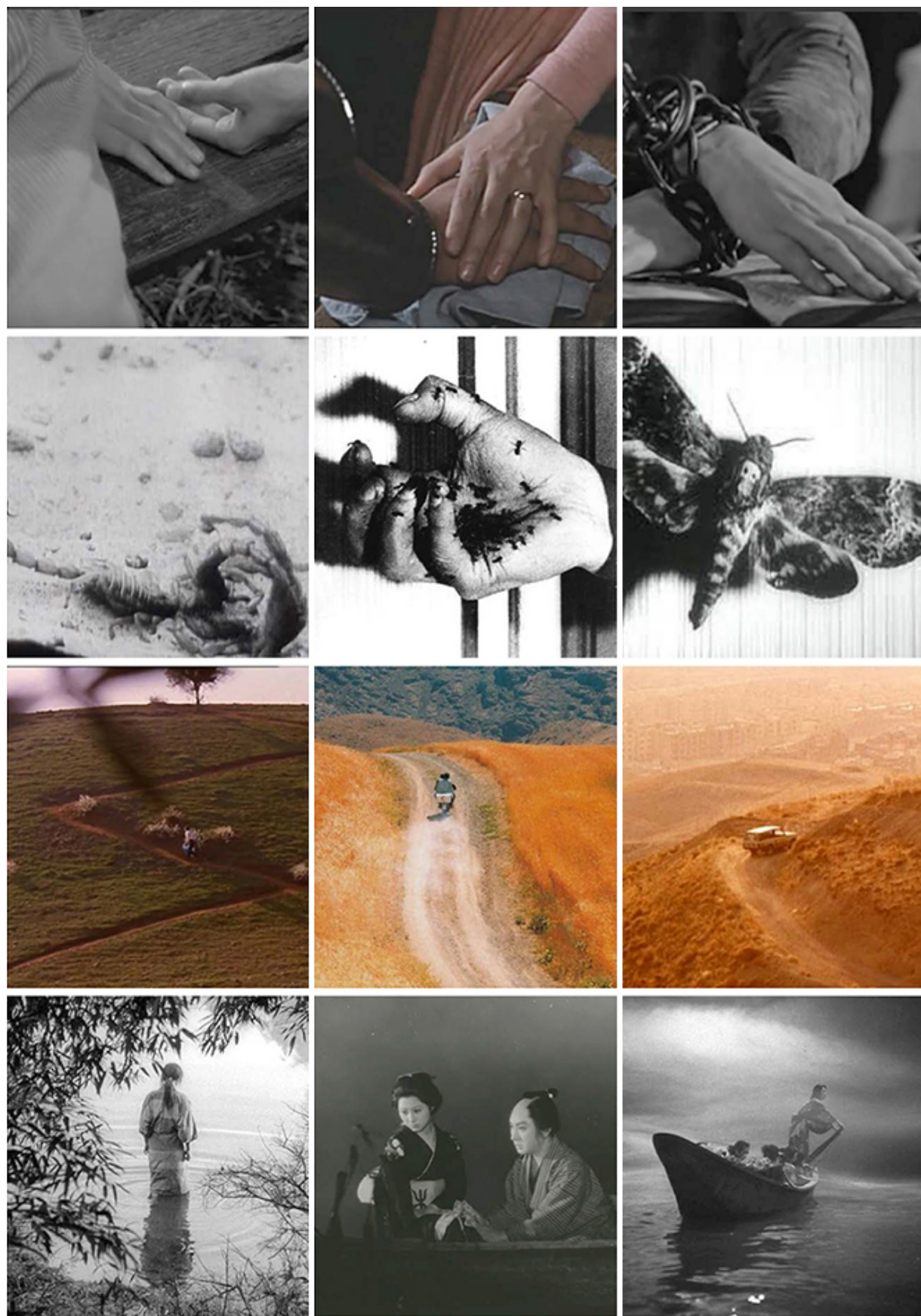

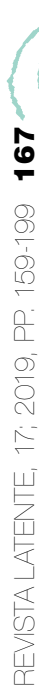

Motivos visuales. Primera fila, las manos en Bresson; segunda fila, los insectos en Buñuel; tercera fila, los caminos de Kiarostami; y última fila, los lagos en Mizoguchi. 


\section{LOS MOTIVOS VISUALES EN EL CINE DE INGMAR BERGMAN}

Volcándonos de lleno en el tema central de este artículo, la filmografía de Ingmar Bergman es una clara manifestación del arte simbólico. Es decir, el simbolo prevalece sobre el signo, lo metafísico ante lo descriptivo. Las imágenes bergmanianas son tomadas por sí mismas (signo), pero más aún por lo que estas significan (simbolo). Jean Mitry afirma en Estética y psicología del cine (1989) que, «si en la literatura el sentido está detrás de la palabra, en el cine no está detrás [...], sino entre las imágenes ${ }^{18}$ ». Esto es llevado por Bergman a la máxima expresión creativa. Los motivos visuales empleados por Bergman toman tal forma y cualidad sensible que podrían definirse como una auténtica manifestación artística.

Aparecen representados en la filmografía del cineasta sueco una infinidad de motivos visuales, muchos de ellos ya establecidos y bien definidos desde sus primeras producciones. Es más, se observa un mayor número de motivos visuales en su primera etapa -finales de los años cuarenta y toda la década de los cincuenta- que en las siguientes, puesto que Bergman opta después por centrarse en determinados motivos relacionados con la problemática de Dios, la incomunicación, la carencia afectiva y la muerte. Bergman construye sus escenas en esta primera etapa empleando un rico repertorio de motivos visuales cuyo origen viene de sus experiencias y recuerdos, especialmente aquellos pertenecientes a su infancia y juventud. No obstante, Bergman reconoce que no alcanza el depurado nivel narrativo de un escritor, por lo que remedia esta carencia empleando «la yuxtaposición de secuencias verbalizadas con escenas de fuerte carga visual ${ }^{19}$ » en base a motivos visuales y recursos compositivos. Esto permite una buena fluidez tanto en ritmo como en expresión narrativa.

Por ejemplo, cuando vemos algunos personajes de sus películas que están contemplándose ante un espejo, en muchos casos no es una acción desinteresada y carente de significación. Dicha acción en el cine bergmaniano alude normalmente a conflictos emocionales. En la película Crisis (Kris, 1946), la actriz Marianne Löfgren interpreta a la señora Jenny, una mujer entrada ya en la cincuentena que se observa angustiada frente a un espejo. Aquí se nos presenta un momento de reflexión en el que Bergman intenta transmitir lo que su personaje siente utilizando únicamente los lenguajes visual y simbólico. Jenny contempla su reflejo y lo que ve no le gusta. No consigue reconocerse. Ella es incapaz de aceptar que envejece. El espejo le devuelve un reflejo que se aleja de la joven hermosa, deseada y triunfadora que una vez fue. Y, para reforzar aún más lo que representa el espejo en esta escena, aparece reflejada la cabeza de un maniquí que viene a hacer alusión al mundo de las apariencias, lo artificial, lo que no somos, pero que en el fondo ansiamos ser. El cine está lleno de mujeres y hombres que contemplan con impotencia su reflejo. En Noche de estreno (Opening Night, John Cassavettes, 1977), Gena Rowlands interpreta el papel de

${ }_{18}$ Mytri, J. (1989): Estética y psicología del cine, Madrid, Siglo xx de España Editores, p. 547.

19 Hinojosa, H.A. (2009): Imágenes y palabras en el cine de Ingmar Bergman. Consultado el 23 de junio de 2018, de https://hugoalfredohinojosa.wordpress.com/2009/10/21/el-cine-de-bergman/. 

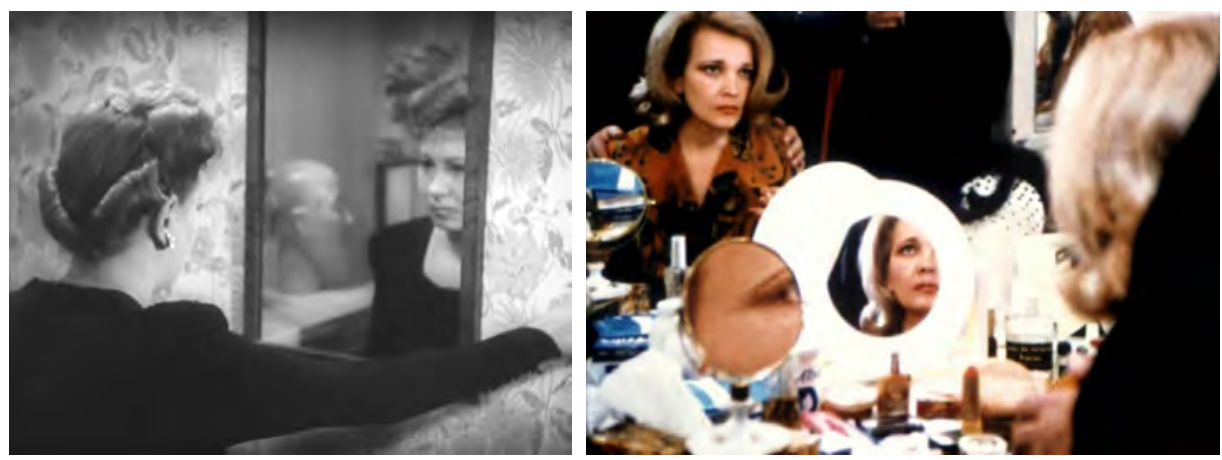

Escena de las películas Crisis (Ingmar Bergman, 1946, imagen derecha) y Noche de estreno

(John Cassavettes, 1977, imagen izquierda). Ambas mujeres confrontan la imagen que les devuelve el espejo: un reflejo que habla del miedo a envejecer.

Myrtle Gordon, actriz a la que, al igual que Jenny, se le hace insoportable el hecho de envejecer. Ni Myrtle ni Jenny dicen ni una palabra de lo que sienten al respecto. Solo ellas, una mirada, un espejo y la historia en la que están inmersas bastan para que el espectador pueda interpretar lo que les ocurre.

En el presente artículo nos centraremos en los motivos visuales más definitorios de la obra cinematográfica de Ingmar Bergman: el espejo, el erotismo y la muerte. El espejo que, además de representar el paso inequívoco del tiempo y la nostalgia que esto genera, tal y como se demuestra en el ejemplo citado anteriormente, también tiene otros significados de carácter simbólico. Por otro lado, el erotismo se manifiesta especialmente en motivos visuales como el cigarrillo, la cama y la desnudez. Salvo contadas ocasiones y a causa de la censura de la época, Bergman opta por desnudos parciales o fuera de campo que no dejan de tener una importante significación en su cine. Por último, podemos encontrar otros motivos visuales relacionados con la muerte, en donde destacan los motivos de la pistola, el ajedrez o el concepto simbólico creado por Bergman conocido como la doble muerte.

Gracias a este lenguaje cinematográfico de fuerte carácter simbólico, compuesto por motivos visuales, ya sean universales o específicos ideados exclusivamente por el autor, el espectador es consciente de lo que quiere dar a entender en determinada escena, sin necesidad de que el personaje haga un largo e innecesario monólogo literario diciendo qué piensa o qué siente. Podemos mencionar de nuevo a Mitry para citar de nuevo esta idea:

Lo esencial del lenguaje no radica ni en la manera de decir ni en los medios empleados, radica en el hecho indiscutible de significar, es decir, de acceder a un sentido por medio de símbolos, sean o no transparentes ${ }^{20}$.

${ }^{20}$ Mytri, J. (1989): op. cit., pp. 547-548. 
Ingmar Bergman, como buen conocedor de las aptitudes que pueden ofrecer los motivos visuales, sabe darles uso y de manera tan creativa que sobra decir que alcanza una virtud poética.

\section{EL ESPEJO}

El ser humano siempre ha sentido una fascinación indecible por los espejos. Ya desde la Antigüedad se le atribuyen poderes mágicos, así como diferentes connotaciones simbólicas ${ }^{21}$. El arte de la pintura adapta en muchas ocasiones los atributos y funciones del espejo. Un ejemplo lo tenemos en el arte del retrato, que luego alcanza su mayor auge con el nacimiento de la fotografía. Por otro lado, el cine en sí mismo puede entenderse como un espejo: una pantalla capaz de reflejar la realidad a la perfección. Pantallas dentro de pantallas; reflejos múltiples y laberínticos. En consecuencia, el simbolismo del espejo va más allá en la cinematografía que lo realizado en la pintura o en la fotografía.

El motivo visual del espejo cuenta con diferentes atribuciones simbólicas y Bergman hace uso de muchas de ellas para plasmar sus reflexiones más personales. Analizaremos las siguientes, en donde el espejo es comprendido como:

- Representación de la verdad.

- Símbolo de la vanidad.

- Puerta que conecta con el más allá.

- Representaciones de la nostalgia y la pérdida.

- Manifestación del doble.

\section{EL ESPEJO COMO REPRESENTACIÓN DE LA VERDAD}

En términos generales, el motivo visual del espejo se concibe normalmente como algo más real que la propia realidad ${ }^{22}$. Representa la verdad, lo existente y la autoconciencia. Los personajes pueden ser y actuar como no son realmente, pero ante el espejo, el reflejo que les es devuelto muestra su verdadera naturaleza: miedos, anhelos, reflexiones, culpas, obsesiones... Enfrentados al juicio de su propio reflejo,

${ }^{21}$ Desde la Antigüedad se le atribuyen al espejo connotaciones mágicas y religiosas. Aparece en incontables mitos y leyendas en donde tiene las cualidades de proyectar imágenes del pasado y del futuro -como la leyenda que cuenta acerca de las visiones futuras que tiene María Antonieta al contemplar los espejos del hipnotista y médico Franz Anton Mesmer-, de mostrar siempre la verdad -como el famoso espejo de la madrastra de Blancanieves o el escudo de Perseo en el que refleja el grotesco rostro de Medusa- o de servir de puerta de conexión entre el mundo de los vivos y el de los muertos -como el espejo mágico utilizado por Isis para traer de nuevo a la vida a Osiris una vez recogidas todas las partes de su cuerpo-.

22 Balló, J. y Bergala, A. (eds.) (2016): op. cit., p. 188. 
no necesitan expresarse mediante diálogos ni largos monólogos para que el espectador deduzca cuáles son sus conflictos internos. Esta característica hace del espejo un enemigo: desenmascara emocionalmente a los personajes quedando indefensos ante esa mirada acusatoria que vierten hacia sí mismos.

Luque afirma en su libro Bergman: el artista y la máscara (2007) que «la diferencia entre la personalidad pública o profesional que uno se ha forjado en la vida y la verdadera persona que uno es, el auténtico ser humano que somos por dentro, en lo más profundo de nuestra alma ${ }^{23}$ ", es algo que atormenta tanto a Bergman como a sus personajes. Hay que recordar aquí que Bergman se define a sí mismo como un maestro del engaño y otorga a esta consideración un efecto negativo. Ama la verdad sobre todas las cosas, pero detesta lo desgarradora que puede llegar a $\operatorname{ser}^{24}$.

En una escena del film Fresas salvajes (Smultronstället, 1957), el anciano Isak Borg, el protagonista, se nos presenta en uno de sus sueńos. Se encuentra en medio de un paisaje bucólico y en compañía de Sara, su primer amor. Ella se muestra joven y hermosa, tal y como Isak la recuerda. Sara permanece sentada frente a Isak sujetando un espejo y le insiste en que se contemple en él, pero este se niega. El espejo es aquí una manifestación dolorosa de la autoconciencia: le devuelve sin piedad los aspectos del yo que el protagonista quiere ignorar. Isak ha llegado al ocaso de su vida y se arrepiente de haber sido tan rígido y egoísta con sus seres queridos, como por ejemplo con Sara, a la que acabó perdiendo. Remitiendo de nuevo a Luque, el personaje de Isak Borg «simboliza una de las peores miserias que caracterizan al hombre moderno: el miedo a demostrar sus propias emociones y a la imposibilidad que tiene de comunicarse con los demás ${ }^{25}$ ".

Hay escenas similares a lo largo de toda su filmografía. La sed (Törst, 1949) cuenta la historia de Ruth y Vagnora, cuya relación de tintes ambiguos es desaprobada por la directora de la academia, quien apuesta por las aptitudes de Vagnora y cree que Ruth acabará perjudicando su carrera como bailarina profesional. En una escena, la anciana aparece reflejada en un espejo: simboliza la voz de la experiencia, pero también en lo que Vagnora se convertirá - una exbailarina sin éxito-si desoye sus consejos. En otro están reflejadas Ruth y Vagnora representando lo que justamente son: jóvenes impulsivas que sin temor afrontan lo que les pueda deparar el futuro.

En Gritos y susurros (Viskningar och rop, 1972) se nos presenta la relación matrimonial de Karin y Fredrik. La distancia y la carencia afectiva hacen mella en Karin, que, según Luque, busca «la necesidad de sentir algo, lo que sea, aunque se trate de dolor ${ }^{26}$. Karin no duda en hacerse daño con un pedazo de cristal, el cual aparece en una escena descansando sobre un espejo.

${ }^{23}$ Luque, R. (2007): Bergman: el artista y la máscara, Madrid, Editorial Ocho y medio, p. 46.

24 Bergman, I. (1988): op. cit., p. 18.

${ }^{25}$ LuQue, R. (2007): op. cit., p. 48.

26 Ibid., p. 72. 

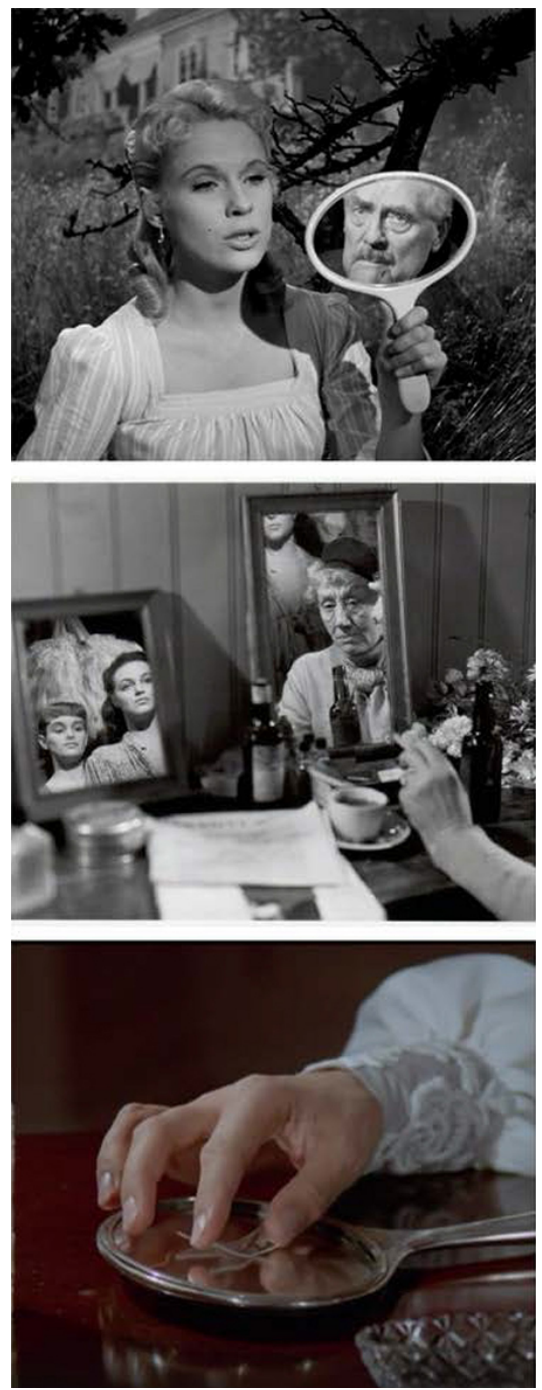

El espejo como representación de la realidad en Fresas salvajes (arriba), en La sed (centro) y en Gritos y susurros (abajo).

EL ESPEJO COMO SÍMBOLO DE LA VANIDAD

La acción de mirarse en un espejo se la considera una expresión de la vanidad. Además de esto, simboliza la superficialidad, el valor que es otorgado a la apariencia, al ego y a los placeres carnales. En toda la filmografía de Bergman aparecen jóvenes actrices que se contemplan en los espejos admirando su belleza. Muchas de ellas sacan provecho de esta condición para manipular a otros personajes, espe- 


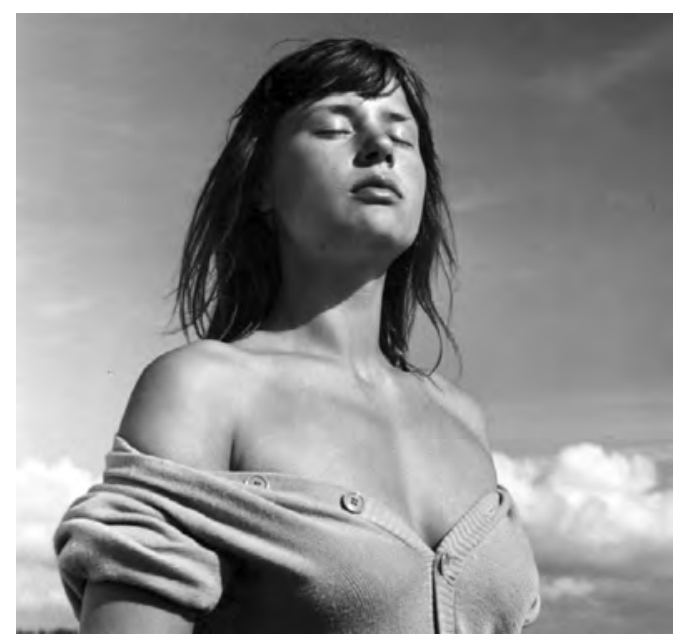

La actriz Harriet Andersson en Un verano con Mónica.

Aquí el mar adopta el papel simbólico del espejo, el cual refleja la belleza salvaje y poco convencional de Mónica. (Fuente: Stiftelsen Ingmar Bergman (http://www.ingmarbergman.se).

cialmente hombres, asumiendo el papel de femme fatale. Uno de los personajes que asume este papel y lo desarrolla mediante el motivo visual es Mónica, de la película Un verano con Mónica (Sommaren med Monika, 1953), pero lo hace de manera realista: ella es vulgar, impulsiva y caprichosa porque simplemente quiere sentirse libre.

Mónica se contempla en prácticamente todos los espejos que aparecen en la película; masca chicle y fuma sin parar -hábitos que por aquel entonces se describían como masculinos-; habla y actúa con desfachatez; no se maquilla ni recoge sus cabellos en complicados peinados; y es la que lleva los pantalones en su relación amorosa con Henrik, el protagonista.

Está claro que Mónica no es la típica chica frágil del cine clásico, pero tampoco es la elegante calculadora femme fatale del cine negro. Mónica es simple, natural. Quiere para sí la independencia que, por el mero hecho de ser mujer, se le es negada. Hay que entender que la historia se desarrolla en el marco histórico de la posguerra, en el que la mujer sigue atada a las convenciones misóginas impuestas por la sociedad. Como femme fatale, a Mónica se la considera una amenaza ya que rompe con la idea tradicional que se tiene de la mujer, destinada al servicio del hombre y al cuidado de su prole ${ }^{27}$. Mónica define la nueva imagen de la mujer contemporánea. Además, hay una reversión del rol hombre-mujer en el film. Mientras que Mónica se dedica a divertirse por ahí y a seducir a otros hombres, Henrik permanece en casa haciéndose cargo del bebé.

27 SiClier, J. (1962): Ingmar Bergman, Madrid, Ediciones Rial, pp. 100-101. 

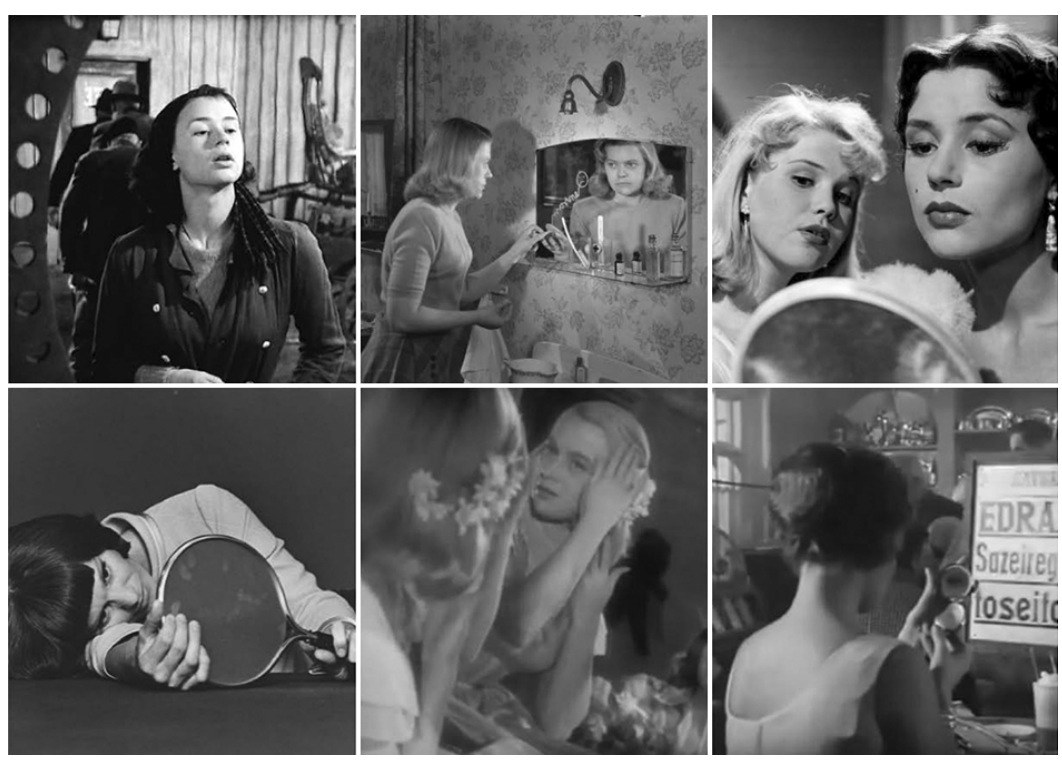

Ejemplos en el cine de Bergman de la vanidad, figurada en la contemplación del espejo.

Otras mujeres del cine de Bergman, en cambio, admiran su belleza porque empiezan a ser conscientes de su feminidad. En la película Música en la oscuridad (Musik i mörker, 1948), una anciana sirvienta le dice a otra que es adolescente y no para de mirarse en el espejo: «iYa te has vuelto vanidosa y engreída?».

Hay que mencionar que Bergman siempre se ha interesado por los temas que tratan sobre la mujer. De hecho, su cine se podría definir como uno en el que predomina la figura de la mujer sobre la del hombre. Bergman desarrolla temas femeninos como la fragilidad emocional, las insatisfacciones amorosas, las diferentes edades por las que pasa la mujer y el importante papel ejercido por la madre, la hermana, la amante y la esposa.

\section{El ESPEJO COMO PUERTA QUE CONECTA CON EL MÁS ALLÁ}

Desde época antigua, se le ha asignado al espejo la función de puerta que da acceso al mundo de los muertos y por la cual transita el alma una vez que abandona el cuerpo ${ }^{28}$. Bergman expresa este contenido simbólico en su película Como

28 Según Cirlot en Diccionario de símbolos, de esta concepción simbólica atribuida al espejo surge la tradición de cubrir los espejos o la de colocarlos de cara a la pared cuando alguien muere en el hogar. Cirlot, J.E. (2004): Diccionario de simbolos, Barcelona, Siruela, p. 202. 
en un espejo (Såsom i spegel, 1961), perteneciente a la primera trilogía y cuyo tema central se basa en el problema de Dios, manifestado en el personaje de Karin, una joven esquizofrénica, "cuya locura es al mismo tiempo lucidez ${ }^{29}$ ".

Un día, Karin deambula por el ático de su casa de verano y contempla la luz del amanecer reflejada en el mar-que toma el papel simbólico del espejo-y que al mismo tiempo se proyecta en una de las paredes. Karin se concentra tanto en esta visión que alcanza el éxtasis místico: escucha la voz de alguien que surge del mar y a ella no le cabe duda de que es Dios quien habla. Esta no es la primera experiencia de Karin con el mar. En algunas conversaciones que tiene con sus familiares, especialmente con su hermano, conocemos que ella ya ha tenido este tipo de experiencias en donde ha sido capaz de hablar con muertos. Finalmente, Karin decide ingresar en un centro psiquiátrico porque, según ella, «no se puede estar entre dos mundos. Hay que elegir». Y Karin elige vivir.

Otro ejemplo destacable lo tenemos en El rostro (Ansiktet, 1958), momento en el que el mago Albert Emanuel Vogler muere al ser atacado por un hombre que asiste a uno de sus espectáculos de magia. En esta escena el cuerpo de Vogler aparece reflejado en un biombo de espejos como si quisiera representar el tránsito de su alma hacia el otro lado. En este film también vemos cómo Vogler reaparece más tarde como un fantasma que, ávido de venganza, se le aparece a un médico que se burlaba de sus habilidades mágicas y le da un susto de muerte. El médico nota su presencia en el espejo y queda tan horrorizado que es incapaz de moverse, como si Vogler llegara del mundo de los muertos.

\section{EL ESPEJO COMO REPRESENTACIÓN DE LA NOSTALGIA Y LA PÉRDIDA}

El espejo, aparte de permitir el tránsito de las almas, también es capaz de evocar recuerdos, especialmente aquellos que están teńidos de amargura, que se extrańan porque se han disuelto en el pasado y no han podido llegar al presente. La añoranza por un amor, un ser querido o una vida próspera que ya no se tienen son ejemplos claros cuando un personaje los rememora ante un espejo. Por ejemplo, en el film Un verano con Mónica, el protagonista se contempla en un espejo. Recuerda apenado los buenos momentos que vivió junto a Mónica antes de que ella lo abandonara, dejándolo con el bebé de ambos. En Barco a la India (Skepp till India land, 1947) se nos cuenta la historia de un padre de carácter opresor y violento, agresivo con su familia y compañeros de trabajo. En una escena, este se contempla en el espejo de su habitación y asume apesadumbrado que ha perdido la autoridad que hasta ahora había tenido desde su juventud, amenazada por la presencia de su hijo, quien ha dejado de ser un niño y no duda en plantarle cara.

29 Wood, R. (1972): op. cit., p. 119. 


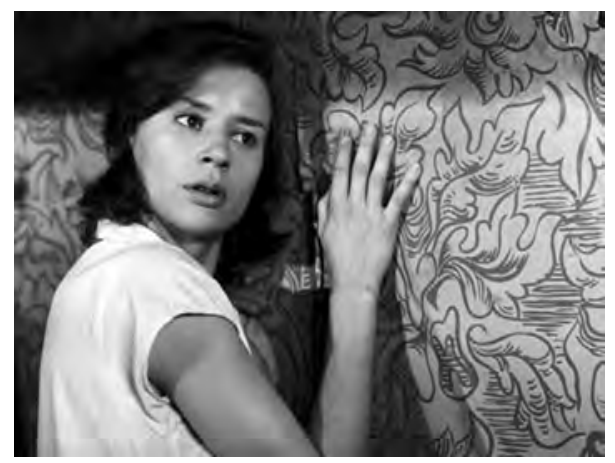

La luz de la mańana baña la costa y se refleja en la pared y en el rostro de Karin (Harriet Andersson) en una de las escenas más representativas de Como en un espejo. Karin está a punto de experimentar una conexión mística con el mundo de los muertos y con Dios. El mar toma aquí el valor simbólico del espejo.

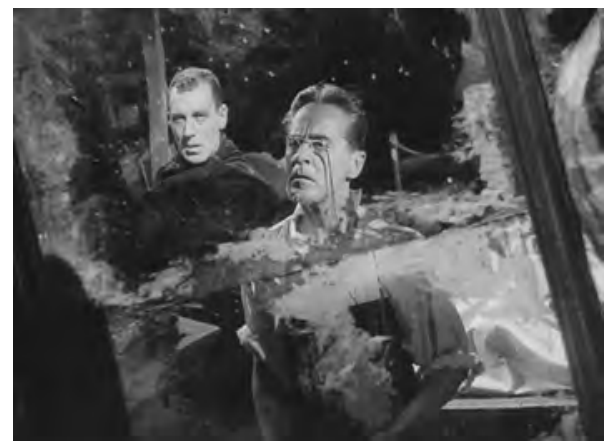

Albert Emmanuel Vogler (Max von Sydow), situado al fondo, como una aparición fantasmagórica que surge del espejo en El rostro.

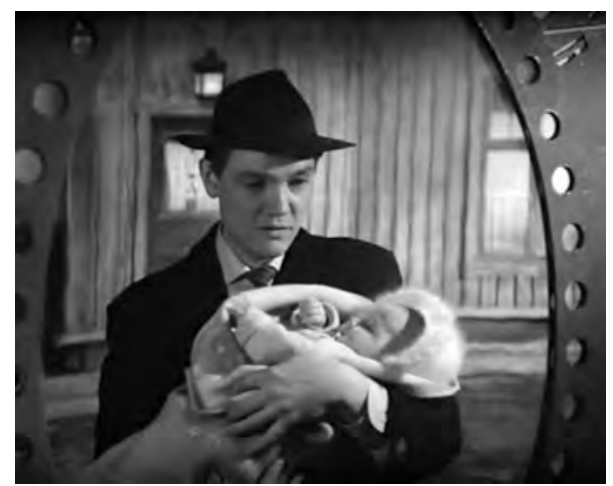

La nostalgia de Henrik (Lars Ekborg) vista a través del espejo en Un verano con Mónica. 
La nostalgia por la juventud también se observa en personajes como Jenny en Crisis-ya comentado anteriormente-y en Tim Mandelbaum en De la vida de las marionetas (Aus dem Leben der Marionetten, 1980). Tim es homosexual y está enamorado de su amigo Peter, quien está casado con Katarina. Tim se lleva bien con la pareja, pero en el fondo odia a Katarina porque es una mujer hermosa, está en la flor de la juventud y posee el afecto de Peter. En una escena en la que comparte confidencias con Katarina, Tim realiza uno de los mejores monólogos del cine bergmanianos -junto con el del caballero Antinious en El séptimo sello (Det sjunde inseglet, 1957) y el de la enfermera Alma en Persona (Persona, 1966)-, y lo hace frente a un espejo. Tim contempla frustrado su propio reflejo; se desprecia a sí mismo. Anhela ser joven de nuevo y asíl llevar una vida diferente a la que le ha tocado vivir.

\section{EL ESPEJO COMO MANIFESTACIÓN DEL DOBLE}

Por último, pero no menos importante, está el valor simbólico que Bergman otorga al espejo como manifestación del doble. Su film Persona está protagonizado por dos mujeres de caracteres opuestos, dos conciencias que se fusionan en una sola después de contemplarse en un espejo hipotético -la pantalla- e intercambian sus identidades, desprendiéndose así de sus respectivas máscaras -la apariencia-. Alma es humana, emocional y espontánea; representa nuestro lado más banal. Por el contrario, la culta y enigmática Elizabeth «encarna los niveles más altos de nuestra conciencia ${ }^{30}$. Bergman en su autobiografía Imágenes (1992) expresa lo siguiente:

Ambas intercambian sus caracteres. Elizabeth ahora es Alma y habla con su voz [y viceversa]. Sentadas una frente a la otra se hablan con tonos y gestos, se atormentan, se insultan y se torturan, se ríen y juegan. Es una escena-espejo ${ }^{31}$.

El simbolismo del doble dentro del motivo visual del espejo representado a la manera de Bergman fue imitado posteriormente por otros cineastas. En Mullholland Drive (David Lynch, 2001), Betty y Rita van compartiendo e intercambiando rasgos de su personalidad a lo largo de la película. En Les Biches (Claude Chabrol, 1968) y en Three Women (Robert Altman, 1977) cuentan la historia de dos mujeres cuya extraña relación acaba en un intercambio de personalidades: tú eres yo, y yo soy tú. Por otro lado, en De la vida de las marionetas volvemos a centrarnos en el personaje de Tim Mandelbaum. Habíamos dicho en el apartado anterior que le aterra envejecer. En la escena del monólogo del que hablamos anteriormente, Tim en realidad está teniendo una conversación con su yo del espejo. En este caso, el espejo cumple el papel del doble. Mientras que Alma y Elizabeth encuentran el equilibrio en la simbiosis de sus identidades, Tim lo encuentra en el desdo-

\footnotetext{
30 Wood, R. (1972): ibidem, p. 167.
}

31 Bergman, I. (1992): op. cit., p. 77. 

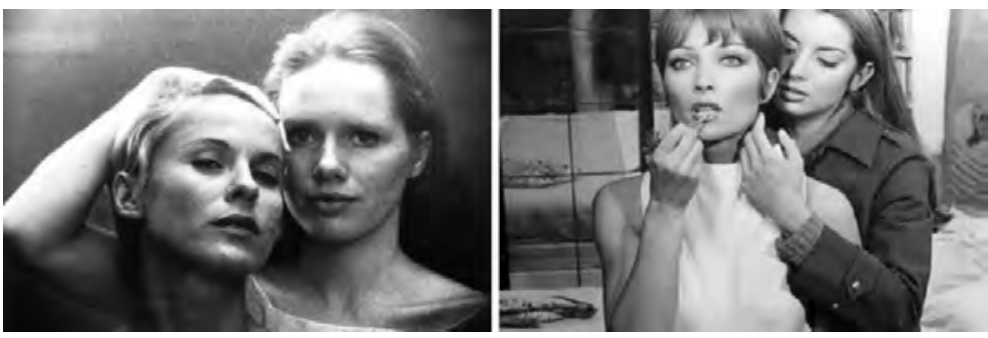

La pantalla convertida en el reflejo. Persona (izquierda) y Les Biches (derecha).
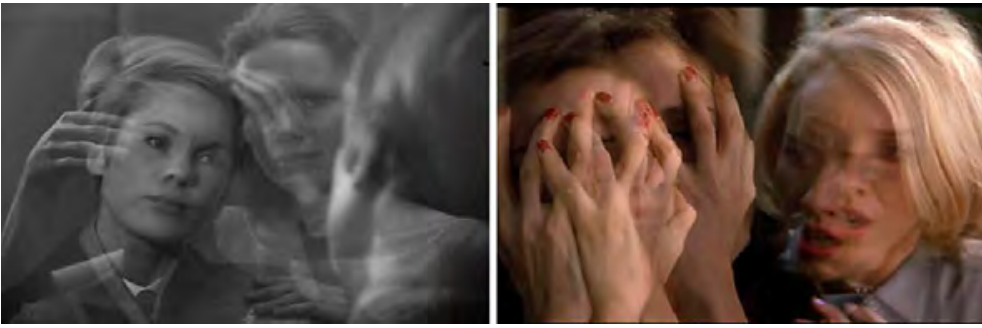

Desdoblamiento en la escena-espejo. Persona (izquierda) y Mulholland Drive (derecha).
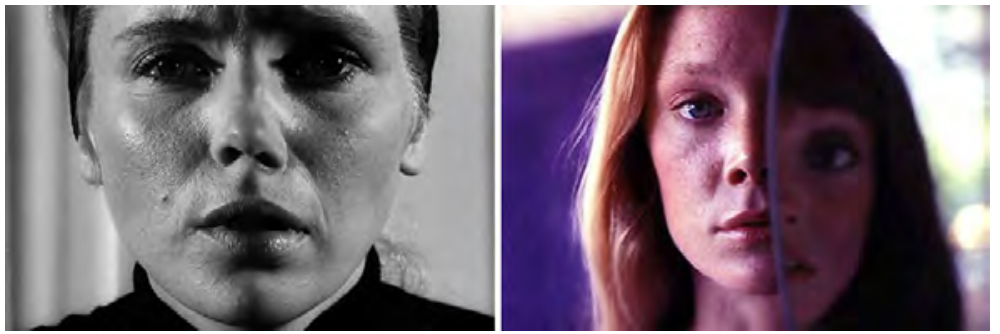

Fusión de dos rostros en uno. Persona (izquierda) y Three Women (derecha).

blamiento de la suya: su lado benévolo, por un lado; su lado caótico, por otro. Esto lo explica en su monólogo:

Son fuerzas secretas. ¿Cómo se llaman? No lo sé. Puede que sea el mismo envejecer, la putrefacción. No lo sé. Fuerzas que no puedo controlar. Observo mi cara en el espejo. Me es bastante familiar. Y constato que en esta combinación de sangre, carne, nervios y hueso hay dos..., no sé cómo llamarlos. Dos entidades irreconciliables. El sueño de cercanía, dulzura y amistad; es decir, lo que está vivo y es bello. Y por el otro lado, violencia, terror y amenaza de muerte [...]. Quizás mis sueños eran demasiado bonitos. Y como castigo, la vida te sacude cuando menos te lo esperas. Como castigo tienes la nariz tan metida en la mierda que casi te ahogas en ella. 


\section{EL EROTISMO}

La representación erótica existe desde la Antigüedad; sin embargo, no alcanza un estatus sociocultural moralmente aceptable o, mejor dicho, más asimilable, hasta el siglo xx, cuando «la reproductibilidad icónica e hiperrealista de la fotografía y luego del cine ${ }^{32}$ » la convierten en un fenómeno masivo que incluso a día de hoy sigue siendo objeto de censura. La sociedad más conservadora ha desarrollado diferentes opiniones sobre la representación del erotismo en el cine, a veces calificándola incorrectamente como pornográfica. La Historia del Cine puede describirse como la Historia de la Censura, la cual mutila su producción, difusión e invención creativa. Los autores Freixas y Bassa explican lo siguiente:

[El erotismo o el sexo en el cine] no deben ser juzgados desde parámetros moralistas ni por los presumibles efectos (disolutos y perniciosos, jfaltaría más!) que causa en la juventud o en los débiles de espíritu, puesto que en tal caso el problema no será de la película sino de sus espectadores. Si se admite de entrada un criterio moral, se debe tener en cuenta cualquier posible moral [...]. Y la admisión de ese criterio moral conduciría a desestimar un film (o una novela, o una estatua) porque su contenido es de determinada filiación política, religiosa, filosófica. Si caemos en la trampa estaremos justificando la recomendación de acatar un criterio moral, aceptaremos la prohibición ${ }^{33}$.

Hay que tener en cuenta que, cuando hablamos de erotismo o del sexo en el cine, debemos diferenciarlos de una película sexual o pornográfica. La representación de un cuerpo humano desnudo no tiene por qué resultar erótica o que implique un lenguaje sexual. Del mismo modo, las películas de contenido erótico no necesariamente deben incluir desnudez o escenas de sexo. Una mirada sugerente puede sacudir más mentes que un desnudo. Basta con hacer mención de Rita Hayworth y lo que es capaz de suscitar con solo quitarse un guante en Gilda (Charles Vidor, 1946); a Lauren Bacall y la sensual soltura con que enciende un cigarrillo en Elsueño eterno (The Big Sleep, Howard Hawks, 1946); a la icónica escena de Marilyn vestida de blanco y enseñando sus piernas de escándalo en La tentación vive arriba (The Seven Year Itch, Billy Wilder, 1955); o a nuestro chico de oro, Clarck Gable, galante sentimental pero descarado a la vez, que provocó auténticos estragos en el público femenino de la época cuando descubrió que el actor no usaba las típicas camisas interiores en Sucedió una noche (It Happened One Night, Frank Capra, 1934). Por tanto, el cine está repleto de escenas de contenido erótico y sexual «aunque los cuerpos vayan vestidos y los actores ni se toquen ${ }^{34}$ ».

32 Gubern, R. (2005): La imagen pornográfica y otras perversiones ópticas, Barcelona, Editorial Anagrama, p. 9.

33 Freixas, R. y Bassa, J. (2000): El sexo en el cine y el cine de sexo, Madrid, Paidós, pp. 11-12.

34 Ibid., p. 12. 

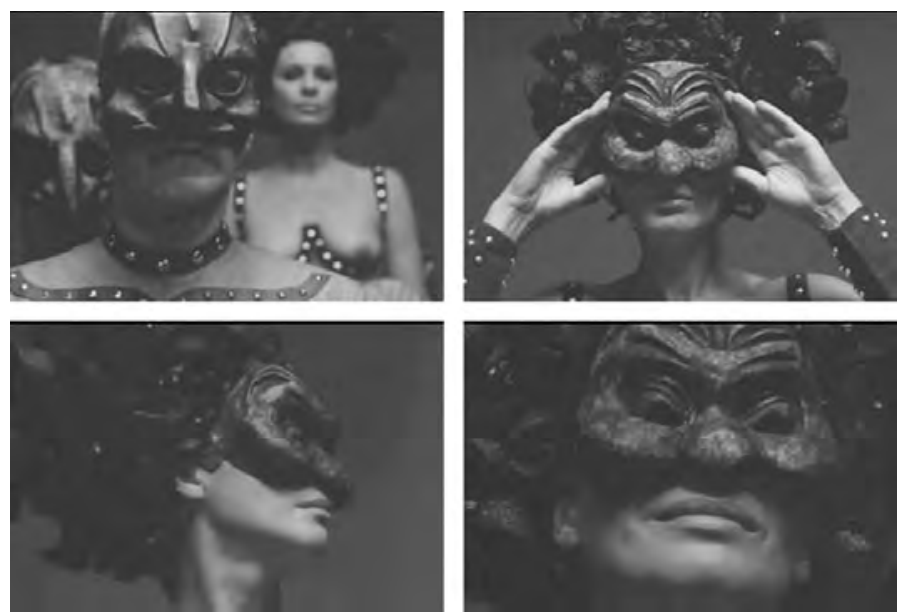

El rito (Riten, Ingmar Bergman, 1969).

Ahora bien, ¿puede el erotismo albergar un valor simbólico? ¿Puede alcanzar un contenido metatextual o no tiene mayor pretensión que la de representar escenas subidas de tono? Independientemente del punto de vista moral que tengamos a la hora de juzgar el erotismo en el arte, es improcedente afirmar que este carece de nociones simbólicas, porque sí las tiene. Sea insinuado o no, esté dentro o fuera de campo, el erotismo aparece en el cine desde sus inicios porque es una realidad inseparable de la condición humana y porque también tiene la capacidad de corresponder con finalidades artísticas, valores e ideas.

A falta de esta doble lectura visual, sería imposible entender el erotismo de la obra de Pier Paolo Pasolini, el cual destila un encanto dramático y metafórico por los cuatro costados; la de Luis Buñuel, que es capaz de describir ambientaciones y aspectos temáticos sin necesidad de acudir a lo explícito; o la de Ernst Lubitsch, quien filmaba imágenes que "proceden de la excitación, de la sugerencia, más de la promesa que del acto ${ }^{35}$ ". Del mismo modo, no se podría comprender plenamente la filmografía de Bergman si limitamos el erotismo que caracteriza muchas de sus películas a meras banalidades y excentricidades proyectadas sin valor alguno por parte del cineasta.

Antes de meternos de lleno con los motivos visuales del erotismo en la obra de Bergman, es importante conocer que a partir de los años cincuenta se producen fases de progresiva permisividad, "conseguida a lo largo de innumerables forcejeos con las instituciones de la censura y los tribunales de justicia ${ }^{36}$ ». Otro hecho que supone un avance contra la censura es el auge del cine independiente que pro-

35 Carrière, J.C. (1997): La película que no se ve, Madrid, Paidós, p. 66.

36 Gubern, R. (2005): op. cit., p. 10. 
duce películas más adultas, las cuales pueden verse en salas de cine de arte y ensayo; mucho más permisivas que las comerciales. En el año 1966 el Código Hays es suprimido, la producción de películas con alusiones eróticas se dispara como la espuma, y ya no solo en el cine independiente sino, que también comienzan a hacerse un sitio en el gran mercado.

Ingmar Bergman fue uno de los pioneros en apostar por el erotismo como un aspecto artístico y simbólico, llevándolo a algo más que a una simple imagen sugestiva con la que atraer miradas y estupores por parte del público, y muecas disconformes por el sector de la censura. Cuando en 1953 -trece ańos antes de que el Código Hays desapareciera- Bergman se atreve a mostrarnos a una descocada y desinhibida Harriet Andersson interpretando el papel de Mónica en Un verano con Mónica, correteando desnuda por la playa durante unos planos memorables, quiere también ofrecernos una significación simbólica importante. La lista de motivos visuales con connotaciones eróticas empleados por Bergman es tan amplia y rica como su filmografía, que evoluciona apostando por unos y abandonando otros según iba renovando su genio creativo; no obstante, podemos nombrar algunos motivos que se mantienen desde el inicio hasta el final de su carrera. Los iremos analizando ahora uno por uno con mayor detenimiento.

\section{El CIGARRILLO}

El cigarrillo está presente en el mundo del cine desde prácticamente su origen. Consigue hacerse un hueco en el cine en blanco y negro puesto que, a falta del color, «el humo contribuía a crear atmósferas brumosas y etéreas, difuminando la luz y acentuando la tensión en escenas interiores ${ }^{37}$ ». Además, muchos actores usaban el gesto de fumar para perfilar la personalidad de sus personajes; la virilidad en los actores, como Humphrey Bogart, o el poder de seducción de las femme fatale, como Marlene Dietrich. Con la implementación del color a partir de los años cincuenta, se reduce el consumo del tabaco porque ya era innecesario su humo a la hora de ambientar escenas pudiendo jugar ahora con la luz y los colores; sin embargo, se mantuvo su valor simbólico, relacionándolo siempre con personajes que tienden a la irreverencia.

Otra atribución simbólica al tabaco es servir como alusión del acto sexual. Debido a la censura, los directores acuden al cigarrillo para dar a entender que los personajes han mantenido relaciones o que las están manteniendo ante la cámara: compartir el cigarrillo se convierte en metáfora del sexo.

Bergman hace uso de esta faceta interpretativa del cigarrillo desde sus inicios como director. La primera película que realiza tomando este concepto es $L a$ sed.

${ }^{37}$ Martínez, A.L. (2017): «El cine y el cigarrillo: una larga historia de odio y amor», El secreto de Berlanga. Consultado el 2 de julio de 2018, de http://www.elsecretodeberlanga.com/2017/11/18/ el-cine-y-el-cigarrillo-una-larga-historia-de-odio-y-amor/. 

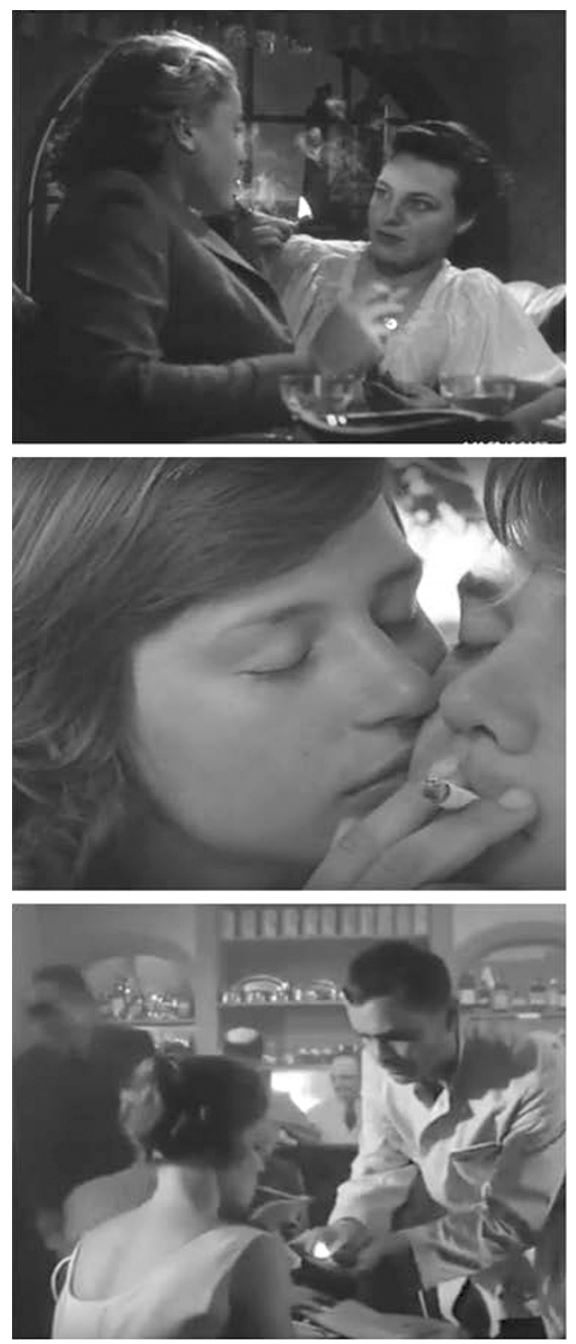

Motivo visual del cigarrillo en La sed (arriba), Un verano con Mónica (centro) y El silencio (abajo).

Vagnora, personaje del que ya hemos hablado, haciendo caso omiso a su directora de ballet, es abandonada por Ruth y se convierte en una mujer solitaria, alcohólica y sin éxito, que se conforma con escuchar música. Un día, se encuentra por la calle a Viola, otra excompañera suya de ballet. Vagnora la invita a su casa y allí, haciendo uso del cigarrillo que comparten, se da a entender que mantienen relaciones sexuales. Bergman explica la escena en su autobiografía Imágenes (1992): 
En una noche estival, las dos mujeres están sentadas juntas y se han bebido una botella de vino. Birgit [Viola] está bastante borracha y Mimi [Vagnora] le da un cigarrillo y se lo enciende. Luego se lleva la cerilla hacia la cara y la sostiene un momento junto a su ojo derecho antes de que se apague. Esto fue idea de Birgit Tengroth. Lo recuerdo de manera muy intensa, ya que yo nunca había hecho nada parecido. El construir a base de detalles apenas perceptibles, sugerentes, se convirtió después en un elemento característico de mi estilo ${ }^{38}$.

Otro ejemplo lo encontramos en Un verano con Mónica. Henrik y Mónica pasan un verano en una playa solitaria alejada de la ciudad. En una secuencia, ellos se intercambian el cigarrillo insinuando una escena de sexo. Mónica dirige la situación adoptando el rol activo mientras que el bueno de Henrik solo se deja llevar, asumiendo el papel tradicional de la sumisión femenina. Todo un escándalo si pensamos que esta película fue rodada en 1953. El cigarrillo compartido también puede aludir a una futura relación sexual entre dos personajes. En Como un espejo, film del que también hemos hablado, se nos presenta a los hermanos Minus y Karin, que fuman juntos en una escena que podría malinterpretarse como romántica puesto que se abrazan y se besan como una pareja. La escena está informando del incesto que se dará más adelante. Por otro lado, la domadora de Noche de circo (Gycklarnas afton, 1953) acaba siendo seducida por un actor de teatro, quien se nos muestra fumando junto a ella en su habitación, momento previo al encuentro sexual. La acción de ofrecer un cigarrillo también puede hacer alusión al ofrecimiento sexual, como ocurre en El silencio (Tystnaden, 1963), en donde la bella Anna consigue fácilmente la atención de muchos hombres para que enciendan su cigarrillo. Otro ejemplo lo vemos en el personaje de Henrik en Un verano con Mónica, quien acepta encender un cigarrillo a Mónica cuando se conocen y, después de intentarlo varias veces sin mucho acierto, lo consigue -acción que representa su inexperiencia amorosa y virginidad-, convirtiéndose así en el nuevo interés romántico de la joven.

\section{LA DESNUDEZ}

Debido a la censura, podemos encontrar en la cinematografía de Ingmar Bergman personajes femeninos que muestran desnudos parciales o de espaldas. Ejemplos relevantes los encontramos en Mónica (Un verano con Mónica), Eva Rosenberg (La vergüenza, The Same, 1968) o Thea Winkelmann (El rito, Ritten, 1969). No veremos desnudos íntegros en sus films hasta los ańos setenta, momento en que comienzan a ser aceptados. De todos modos, Bergman no está interesado en el desnudo, por lo que es utilizado de manera muy puntual si bien cargado de un importante simbolismo. En De la vida de las marionetas, tenemos un desnudo íntegro de la pareja Peter y Katarina. Bergman también opta por los desnudos realizados fuera de campo como el del personaje de Desiree Armfeldt en Sonrisas de una noche de

38 Bergman, I. (1992): op. cit., p. 135. 


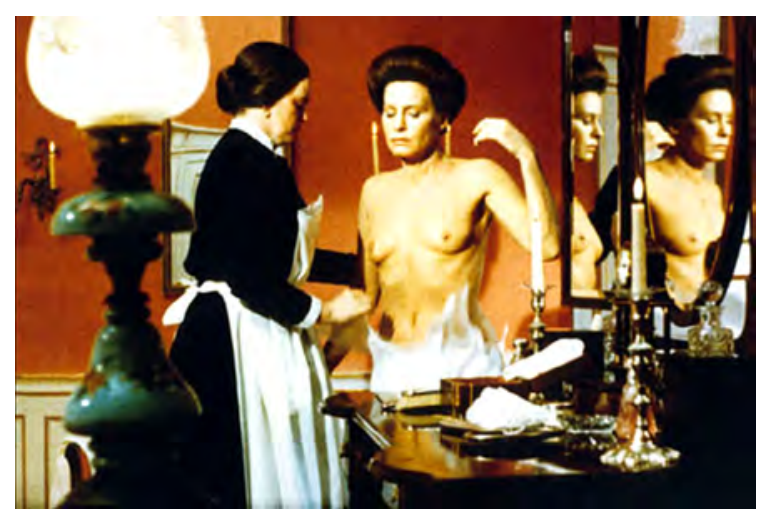

El desnudo de Karin (Ingrid Thulin) en Gritos y susurros.

verano (Sommarnattens leende, 1955) tras un biombo. Otro desnudo fuera de campo se da en un plano del film Un verano con Mónica, cuando la protagonista «muestra las piernas y en acto seguido se quita las bragas para caminar sobre el rostro de su amante tumbado en el suelo boca arriba ${ }^{39}$ ". En lugar de mostrarnos la desnudez de Mónica, Bergman opta por el uso de un plano medio del amante, que, por su reacción, sabemos qué es lo que está sintiendo al presenciar lo que hace ella. Además de ser la desnudez un motivo visual sensualista que atrae la mirada del espectador, siendo esta una de sus principales intenciones, Bergman lo usa también para desarrollar algunas de sus reflexiones. Una de las más utilizadas es el simbolismo de la desnudez como sinónimo de la verdad, de lo que no está contaminado por las apariencias. Para Bergman, plasmar la desnudez es también por el deseo de destapar el alma de sus personajes, su verdadero yo: exhibe sus inquietudes, miedos, anhelos, etcétera. Cuando vemos en Gritos y susurros a Karin siendo desvestida por su criada y quedando desnuda ante la pantalla, tan indefensa y voluble, sentimos que por primera vez en toda la película comenzamos a conocer realmente cómo es. Vestida a la manera decimonónica, con capas y capas de ropa, y expresando siempre un semblante frío y solemne, Karin personifica fielmente a la mujer de su época: una que en silencio lo soporta todo; soledad, incomunicación e insatisfacción afectiva tanto amorosa como fraternal. En su desnudez descubrimos sus sentimientos. Karin odia a sus hermanas puesto que nunca han sido afectuosas con ella y odia también a su marido por lo distante e insensible que es. Karin anhela ser amada de verdad y no sabe cómo salir de esa burbuja burguesa, llena de lujos y comodidades, pero también ensombrecida por la falsedad de las apariencias.

Haciendo uso de esta misma idea, conocemos a Anna en la película Elsilencio. Durante un viaje a un país extranjero junto a su hijo y su hermana mayor Esther,

39 Gubern, R. (2005): op. cit., p. 10. 
Anna decide salir del hotel en el que se hospedan para evadirse y, ¿por qué no?, acostarse con algún hombre. Es una mujer que evoca la juventud, la sensualidad e impulsividad emocional. A pesar de todo, se siente empequeñecida frente a Esther: una mujer culta y elegante que desdeña lo carnal. Cuando Anna está desnuda ante la cámara, su alma queda al descubierto; estamos al tanto de sus pesares más profundos. Si no puede rivalizar en virtudes con su hermana, se limitará a seguir haciendo lo que sabe hacer: disfrutar de la vida y del sexo sin mayores pretensiones, aunque esto en el fondo la haga sentir vacía. Finalmente, tanto en El rito como en De la vida de las marionetas, los desnudos de los personajes principales son un intento por parte de Bergman de mostrarnos también su verdadera naturaleza: una desnudez despojada de las riquezas terrenales y de la ambición ${ }^{40}$. Estos personajes en los que se refleja esta atribución simbólica son Thea Winkelmann (El rito), una actriz teatral cuyo desnudo representa la libertad creativa y la virtud, y la pareja de Peter y Katharina (De la vida de las marionetas), que representa a un matrimonio enfermo que se trata de manera egoísta y se hace daño constantemente. Cuando están desnudos se muestran realmente como son, cuáles son las virtudes y los defectos de su relación. Sus cuerpos reflejan tanto el lado romántico como el tóxico de su relación.

\section{LA CAMA}

Existe un motivo visual en la obra de Bergman que es inamovible: la cama. Las significaciones dadas por el cineasta son diversas: como lugar de encuentro sexual, de conflictos emocionales y de hastío e incomunicación matrimonial. La cama como lugar de encuentro para los amantes se da especialmente en sus primeras películas, donde Bergman aún tiene una visión del amor concebido al estilo más clásico, culminando siempre la historia con un final feliz. Tenemos como ejemplos los encuentros amorosos en mullidas camas de los protagonistas de Crisis, Noche de circo, Barco a la India y Sonrisas de una noche de verano. Por consiguiente, esta concepción simbólica atribuida a la cama abarca desde 1946 hasta 1955. Dicho valor simbólico de la cama no durará mucho, puesto que no refleja las experiencias vividas por el autor, en su mayoría matrimonios y relaciones esporádicas destinados a la separación y al desastre emocional. A partir de mediados de los ańos cincuenta, la cama adopta un nuevo valor simbólico: se convierte en el lugar donde ocurre un conflicto emocional entre dos personajes. De hecho, esta simbología de la cama es por la que más se decanta Bergman. En esta significación uno de los personajes está acostado en una cama pasando por una fuerte crisis emocional mientras que otro intenta acompańarlo y consolarlo. En el film El rostro, la pareja de magos compuesta por Emmanuel Vogler y su esposa mantienen una conversación en la que Vogler revela los pesares que lo atormentan en tanto que es confortado por ella. En Cara a cara (Ansikte mot ansikte, 1976), Tomas intenta consolar a Jenny, víctima de un intento

${ }^{40}$ Cooper, J.C. (2002): Diccionario de simbolos, Barcelona, Editorial Gustavo Gili, p. 66. 


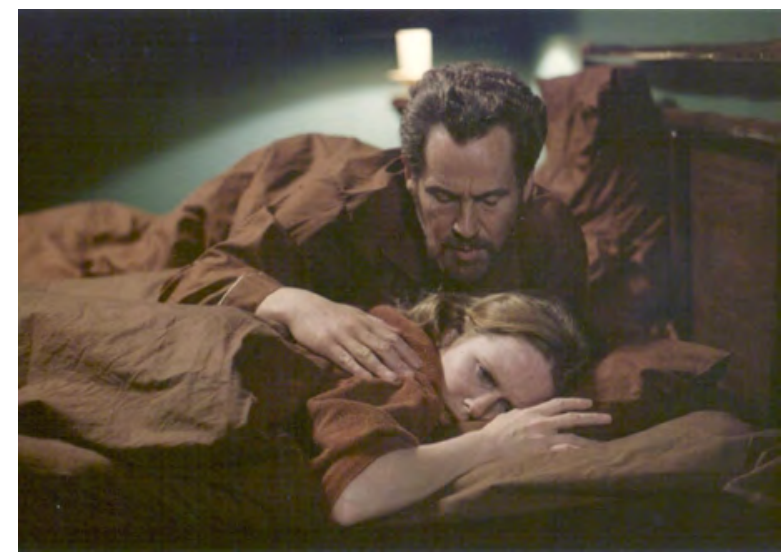

Tomas (Erland Josephson) y Jenny (Liv Ullmann) en Cara a cara.

de violación. Y en Persona, vemos también cómo Elizabeth consuela a Alma en la cama mientras escucha en silencio sus problemas. En la última etapa cinematográfica de Bergman, el motivo visual de la cama es concebido como el lugar del declive amoroso. El ejemplo más claro lo tenemos en Secretos de un matrimonio (Scener ur ett äktenskap, 1974) y en sus protagonistas: Johan y Marianne. A lo largo de su historia, conocemos su vida diaria, especialmente en los momentos que están juntos en la cama, "hablan con poco apasionamiento ${ }^{41}$ » y se comportan como dos auténticos extraños. Esta frialdad e incomunicación conyugal típica de los matrimonios bergmanianos aparece fielmente representada en la película Fanny y Alexander (Fanny och Alexander, 1982), entre Emelie y el obispo Edvard Vergérus, y en los altibajos de la relación entre Karina y David en La carcoma (Beröringen, 1971).

\section{EL COLOR ROJO}

Cuando hablamos del color rojo en el cine de Ingmar Bergman tendemos a pensar única y expresamente en la película Gritos y susurros, comprendida por el propio cineasta como la única en la que tenía intención de destacar dicho color:

Todo es rojo. [...] Todas mis películas se pueden pensar en blanco y negro, excepto Gritos y susurros. En el guion consta que he imaginado lo rojo como el interior del alma ${ }^{42}$.

41 Luque, R. (2007): op. cit., p. 81.

42 Bergman, I. (1992): op. cit., p. 81. 

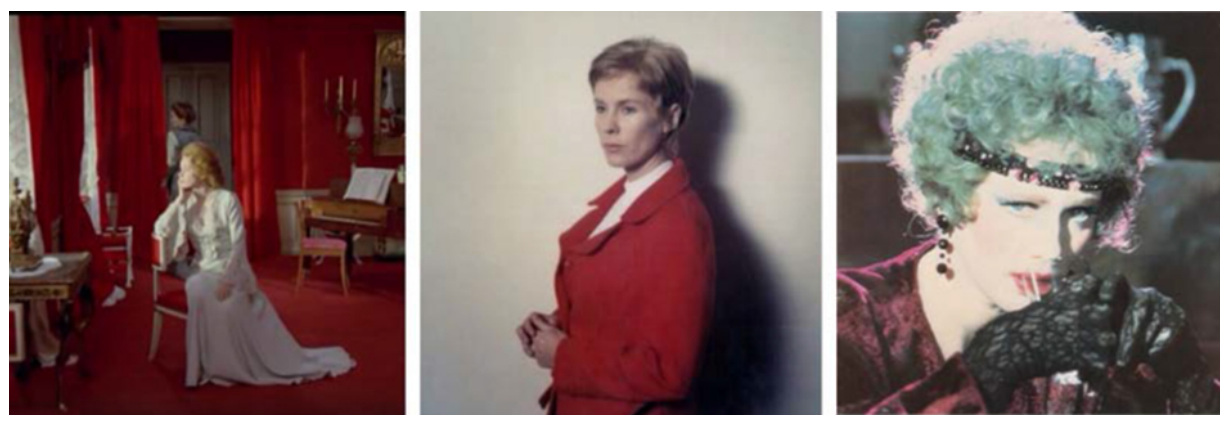

El color rojo en el cine de Bergman. Gritos y susurros (izquierda), La carcoma (centro) y El huevo de la serpiente (derecha).

Este hecho es innegable. El film Gritos y susurros en sí mismo representa todo aquello que define simbólicamente al color rojo: el alma, la fuerza, la salud, el amor, la alegría, la excitación sexual, la energía, la cólera, el dolor, la venganza y la fortaleza ${ }^{43}$. Todos estos temas se manifiestan en la película a través de sus cuatro personajes principales, tres hermanas cuya relación se podría definir como desastrosa, y una criada que en silencio observa la tormenta emocional que sacude a las otras tres.

Gritos y susurros es un recorrido simbólico por el color rojo, desde sus fundidos que inician y finalizan cada una de las historias de los personajes hasta cada rincón de la casa donde se desarrolla la película; paredes, alfombras, vestidos, cortinajes, sofás... Todo compuesto por un rojo vibrante aunque también angustioso, uno cargado de dolor y desesperanza.

Sin embargo, cuando pasamos horas viendo la filmografía del director, concretamente las últimas películas que están filmadas a color, observamos algo que es imposible eludir: el color rojo está presente en cada una de ellas. Y lo que es más, este color es empleado casi siempre para representar la exaltación de la pasión y la sensualidad femenina. El camisón carmesí de María en Gritos y susurros acentúa el lado lujurioso de su personalidad. Harta de su matrimonio, María intenta seducir al doctor que atiende a su hermana enferma.

Este es el mismo rojo que describe collar, labios y lencería de la prostituta estrangulada por Peter en De la vida de las marionetas, y el que viste al reparto femenino de Esas mujeres (För at tinte tala o malla dessa kvinnor, 1964). El rojo forma parte de la vestimenta de Karin Vergérus, personaje de La carcoma, como augurio de su necesidad por adentrarse en el camino de la infidelidad conyugal, y del conjunto en terciopelo de la sensual Manuela Rosenberg en El huevo de la serpiente (Das Schlangenei, 1977) cuando actúa en un burdel. Dicho color está bien estudiado en su

43 Haciendo referencia a las atribuciones simbólicas analizadas por Cooper de dicho color. Cooper, J.C. (2002): op. cit., p. 54. 
cine, en cada objeto, en cada vestimenta. Junto a su director de fotografía predilecto, Sven Nykvist, Bergman "probaba cada objeto delante de la cámara ${ }^{44}$ ». Por tanto, no es mera coincidencia que muchas de sus actrices estén envueltas en un rojo intenso.

\section{LA MUERTE}

Las ideas vitalistas de Søren Kierkegaard y August Strindberg influyeron notablemente en la concepción que tiene Bergman sobre la muerte. Por un lado Kierkegaard habla de la muerte «desde la perspectiva de la incertidumbre, la irracionalidad y la incapacidad de abarcarla por completo» ${ }^{45}$, por lo que el tratamiento que hace de su motivo aparece disperso en su obra. Bergman imita la forma que tiene Kierkegaard de afrontar el hecho de morir: es mordaz, pero de matices oscuros y, en ocasiones, depresivos. Kierkegaard (1987) reflexiona sobre esto en su discurso, citado por Gabašova:

¡Qué vida tan vacía y sin sentido! Muere un hombre, organizamos su funeral, le acompañamos en su último viaje y le echamos tres paladas de tierra encima. Llegamos y salimos del cementerio [...] y nos sirve de consuelo que aún nos queda una larga vida por delante [...] ¿Por qué no nos ponemos de acuerdo acerca de este tema de una vez por todas? :Por qué no quedarnos directamente en el cementerio, bajar a la tumba y sortear al pobre que, como el último superviviente, se ocupe de echar tres paladas de tierra del último difunto?46

Esta forma de pensar sobre la muerte es análoga al carpe diem, es decir, la aceptación conciliadora de vivir cada día como si fuera el último, aunada a la idea de que Dios no está (o si está, permanece ausente o como mero espectador de su propia creación), se da en el cine bergmaniano, especialmente en el film El séptimo sello (Det sjunde inseglet, 1957) y en su primera trilogía. Esta se centra en Dios, quien es concebido como un ser silencioso y distante; permite que los crímenes y desdichas sacudan al mundo. Este denominado silencio de Dios solo puede ser explicado de una única manera: Él está ausente y, por lo tanto, no existe. Estamos solos. Abandonados a nuestra suerte, sin esperanzas de redención ni vida después de la muerte. Ante esta situación difícil de asimilar para el propio Bergman, el hombre se siente confundido, incapaz de medir sus acciones y de discernir entre el Bien y el Mal. Y si aún tenemos fe y pensamos que Dios existe, parafraseando a Woody Allen, «estaríamos ante un Dios que realmente ha hecho muy mal las $\operatorname{cosas}^{47}$ ». Este es el leitmotiv de esta primera trilogía, compuesta por las películas Como un espejo (Såsom

44 Bergman, I. (1992): op. cit., p. 89.

45 Gabašova, K. (2014): «Kierkegaard y el concepto de la muerte en el contexto del turismo oscuro", Revista Sincronía, Departamento de Filosofía y Letras de la Universidad de Guadalajara (México), 65, 71-80, p. 71.

46 Ibid., p. 72.

47 Citado por Luque, R. (2007): op. cit., p. 59. 


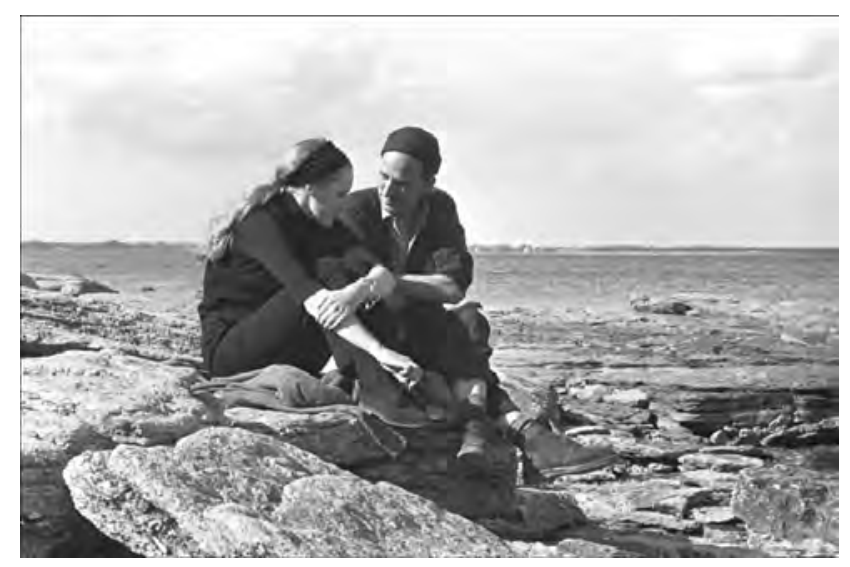

Junto a Liv Ullman en Persona.

Fuente: Stiftelsen Ingmar Bergman (http://www.ingmarbergman.se).

i en spegel, 1961), Los comulgantes (Nattvardsgästerna, 1963) y El silencio (Tystnaden, 1963). La segunda trilogía sigue enfocándose en la problemática de Dios, pero además aborda otros temas tales como la incomunicación entre las personas y la indefinición entre fantasía y realidad. Esta segunda trilogía la componen las películas Persona (Persona, 1966), La hora del lobo (Vargtimmen, 1967) y La vergüenza (Skammen, 1968).

Es importante comentar que Bergman afirma en sus memorias que no concibió estas dos trilogías de esa forma en el momento de su filmación. Es decir, él no estaba planeando realizar trilogías de ningún tipo. La idea de agrupar seis de sus películas en dos trilogías es algo que se pensó más tarde tras una conversación que mantuvo con su amigo Vilgot Sjöman, escritor y director sueco, antes de publicar los guiones. En Imágenes (1992), Bergman sostiene: «Considero que esta reflexión como una forma de racionalizar a posteriori. Contemplo la idea de trilogía con escepticismo. Surgió durante mis conversaciones con Sjöman ${ }^{48}$.

Asimismo, hay que recordar que Bergman realizó un trabajo de fin de carrera sobre la figura y obra de August Strindberg ${ }^{49}$, por lo que es innegable la fuerte influencia que este ejerció en toda su obra. El pensamiento de Strindberg es

48 Bergman, I. (1992): op. cit., p. 215.

49 El escritor Johan August Strindberg (1849-1912) es considerado uno de los autores más importantes de la literatura sueca. Tiene un reconocimiento mundial debido principalmente a sus obras de teatro. Es conocido como el padre del teatro moderno. Comentado por Mandelbaum, J. (2007): Cahiers du cinema. Colección de grandes directores. El libro de Ingmar Bergman, Madrid, Edición particular para el periódico El País, p. 18. 


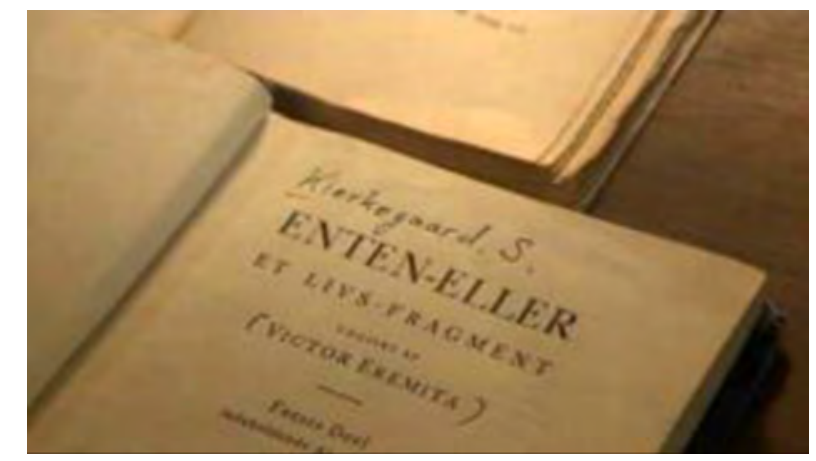

Libro de Kierkegaard titulado O lo uno o lo otro (Enten-Eller 1843)*, que aparece en Saraband, el último film televisivo de Bergman.

igual de desgarrador que el de Kierkegaard. En su libro Danza de la muerte $e^{50}$, un capitán que sufre un repentino ataque cardiaco le pregunta a otro personaje: «crees que voy a morir?». A lo que este le contesta con humor negro para aligerar la situación: «Lo harás como todos. Tú no eres la excepción». Este intercambio de palabras nos remite a una conversación que tiene lugar en El séptimo sello mantenida por la Muerte y Skat, el actor. Skat sube a un árbol para echar una siesta recostado en una de las gruesas ramas y se da cuenta de pronto de que la Muerte está ahí cortando el árbol. «¿No hay reglas especiales para los actores?», le pregunta Skat. Y la Muerte responde, sin inmutarse aunque con ironía: «No, no en este caso». La Muerte prosigue luego con su tarea puesto que todas las personas son iguales para ella. No hay excepciones.

El miedo a morir es, por tanto, una concepción que hace mella en el pensamiento de Bergman y que proyecta obsesivamente tanto en su obra teatral como en la cinematográfica. Asimismo, ya desde pequeńo le aterraba pensar en la muerte. Esta idea se acrecentó al haber sido criado en un ambiente religioso muy estricto. Bergman declara en Imágenes (1992):

Desde que recuerdo he llevado conmigo un profundo miedo enfermizo a la muerte, miedo que durante la pubertad y hasta los veinte y pocos ańos llegó a hacerse insoportable. El pensamiento de que al morir iba a desaparecer, que iba a atravesar el oscuro portal, de que había algo que no podía controlar, ni preparar o prever era para mí un motivo de horror constante ${ }^{51}$.

* Uno de los temas que toca Kierkegaard en este libro es el miedo a la muerte: «Mi voz resuena en el mundo, oídla, todos vosotros, que os llamáis desdichados en el mundo y que no teméis la muerte». Kierkegaard, S. (2006): O lo uno o lo otro, Madrid, Editorial Trotta, p. 29.

50 Projekt Runeberg (2012): Dödsdansen, srikven av August Strindberg. Consultado el 28 de junio de 2018, de http://runeberg.org/dodsdans/.

51 Bergman, I. (1992): op. cit., p. 209. 

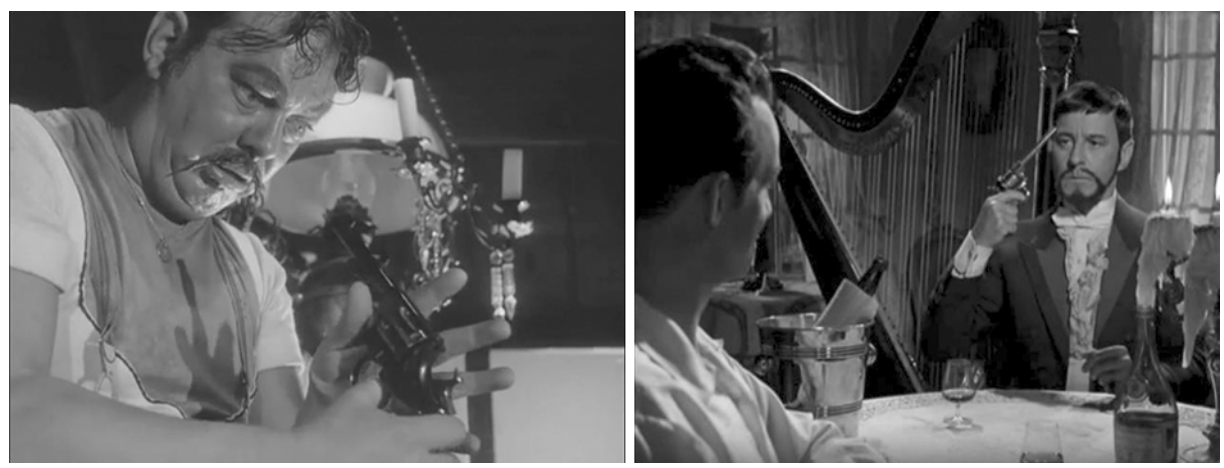

Personajes debatiéndose con su miedo a la muerte usando como motivo visual la pistola en Noche de circo (izquierda) y Sonrisas de una noche de verano (derecha).

Si observamos el tratamiento que hace Bergman del miedo a la muerte en sus primeras películas encontraremos varios monólogos de personajes que deciden suicidarse por una determinada causa, pero su miedo es tan grande que les cuesta dar el paso. Solo unos pocos terminan dándolo, mientras que la gran mayoría desiste y opta por vivir y aceptar las vicisitudes de su existencia. Cuando Bergman trata este tema, emplea motivos visuales típicos como el arma homicida, que suele ser una pistola. En Crisis se nos cuenta el amor tóxico entre Nelly y Jack, un dandi de ciudad fracasado y de tendencias suicidas. En una de las escenas, cuando Nelly decide poner punto final a la relación, él la amenaza con suicidarse de un disparo, pero debido a su miedo a morir aunado a las súplicas de la muchacha, opta por no hacerlo y le entrega el arma. Jack no tardará en sucumbir al suicidio tiempo después cuando pierde definitivamente a Nelly. Un relato similar sucede en Noche de circo, en la que un propietario ambulante llamado Albert, llevado por los caprichosos azares del destino, regresa a la ciudad donde abandonó a su mujer y a su hijo para dedicarse a su nuevo trabajo en compañía de la domadora Anna ${ }^{52}$. Debatiéndose Albert entre quedarse y tener una holgada vida burguesa o seguir con su pasión por el circo aunque viviendo en la miseria, colapsa y pierde el control hasta el punto de querer suicidarse usando su viejo revólver. Finalmente, persuadido por su mejor amigo, el payaso triste -quien irónicamente representa la esperanza y el amor por la vida-, Albert desiste en el intento y baja el arma. También podemos citar aquí al marido de María en Gritos y susurros, quien en un intento por llamar la atención afectiva de su esposa, decide atravesarse con un puñal, pero es demasiado cobarde y termina haciéndose una simple herida superficial. El protagonista de Sonrisas de una noche de verano, Fredrik Egerman, que es desafiado por un rival a jugar a la ruleta rusa, demuestra que siente miedo a morir mientras que a su oponente no parece perturbarle la idea.

52 Siclier, J. (1962): op. cit., p. 106. 


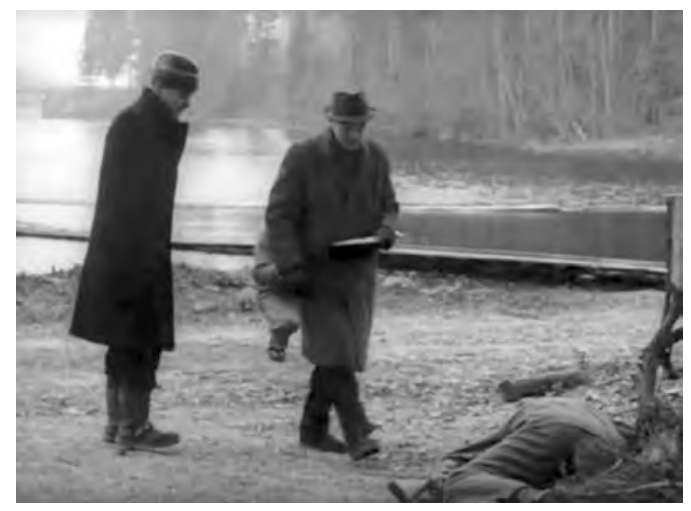

El cuerpo inerte de Jonas (Max von Sydow) es encontrado por las autoridades en Los comulgantes.

Podemos deducir a través de su filmografía que Bergman opta por dignificar más a sus personajes suicidas, cuya valentía los ha liberado de la cárcel de la existencia. Por ejemplo, en su film Prisión (Fängelse, 1949) se nos cuenta la dura vida de Birgitta, una joven que ha sido esclava de la prostitución durante toda su vida. Cuando queda embarazada de uno de sus clientes, tanto su chulo como la novia de este la obligan a abortar. Birgitta, sin más opciones a las cuales aferrarse, lo hace y vive con la esperanza de un mejor porvenir. Ella lo intenta; se enamora de un joven llamado Thomas que, después de acostarse con ella, la abandona a su suerte. Descorazonada y sin expectativas de futuro, decide acabar con su vida.

En Los comulgantes tenemos al personaje de Jonas Persson. Jonas siente amenazada su vida por la guerra. Su temor es tan grande que es incapaz de manejarlo $y$, al igual que Birgitta, ve el suicidio como única salida.

Aparte de la percepción del suicidio como una acción liberadora del alma que en cierto modo responde a consideraciones platónicas, Bergman le ańade también un valor autobiográfico, puesto que se plantea el suicidio en muchas ocasiones a lo largo de su vida. Esto lo explica en Linterna mágica (1988):

Algunas veces en mi vida he jugado con la idea del suicidio, una vez en mi juventud llevé a cabo un torpe intento. Nunca he soñado con hacer realidad mis juegos. Mi curiosidad ha sido demasiado grande, $\mathrm{mi}$ ansia de vivir demasiado robusta y $\mathrm{mi}$ miedo a la muerte demasiado sólido e infanti ${ }^{53}$.

En este caso, Bergman plasma sus experiencias a través de algunos de sus personajes, como el doctor Evald Borg en Fresas salvajes, quien se plantea el hecho

53 Bergman, I. (1988): op. cit., p. 101. 

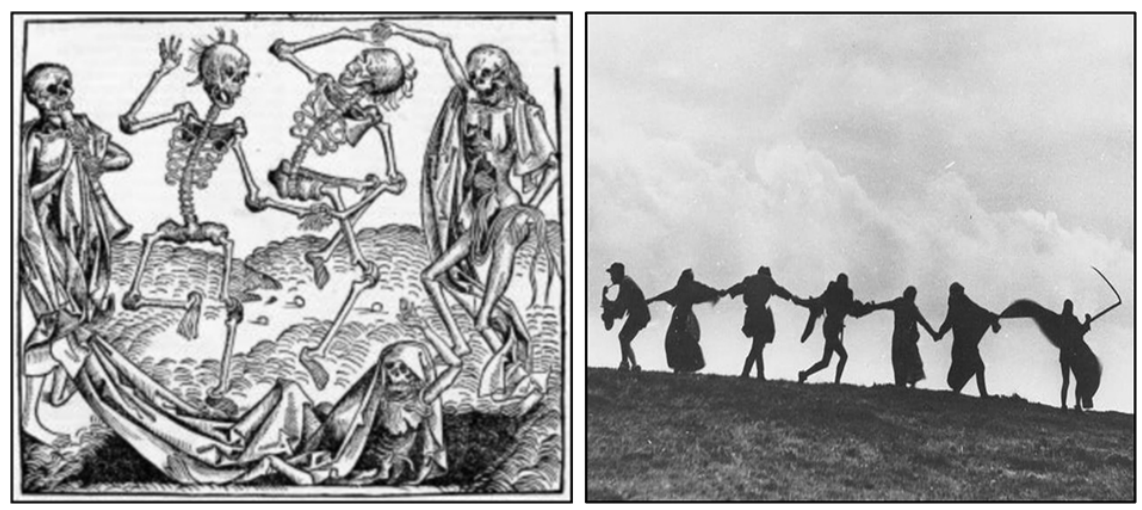

Las danzas de la muerte: grabado realizado por Hans Holbein el Joven (izquierda) y escena de El séptimo sello.

de suicidarse; el conflictivo e idealista Henrik Egerman en Sonrisas de una noche de verano; o el músico que padece de ceguera Bengt Vyldeke en Música en la oscuridad (Musik i mörker, 1948).

La representación iconográfica de la muerte en el mundo occidental se establece y generaliza a partir de la Edad Media. Se la presenta como esqueleto que suele portar un reloj de arena o una guadaña. Normalmente está rodeada por restos humanos como aparece plásticamente en los ciclos de las Danzas de la muerte -Danse macabre $-{ }^{54}$ que "derivan de la impresión causada por las grandes epidemias de peste negra que barrieron a ricos y a pobres, jóvenes y viejos ${ }^{55}$. En su película $E l$ séptimo sello, ambientada en la Suecia del siglo XIV, Bergman no pretende realizar «una visión realista de la vida medieval, sino que es un intento de poesía moderna, pero formada de manera libre en cuanto se refiere a materias medievales ${ }^{56}$ ” $\mathrm{y}$ en el que repite el tema de la danza macabra otorgándole un trasfondo filosófico. Aunque esta historia medieval sea una visión bergmaniana y no histórica, el cineasta sí que toma como referencia la obra plástica medieval, especialmente pinturas, para ambientar escenas y personajes.

En El séptimo sello, el caballero Antonius Block regresa después de haber estado en las Cruzadas junto a su escudero. En una playa solitaria se encuentra a la

${ }^{54}$ El ciclo más famoso que representa las danzas de la muerte es el realizado por Hans Holbein el Joven a principios del siglo XVI, que tendrá una gran difusión en forma de libro en los siglos siguientes. V.g. Martín, S. (ed.). (2001): La danza de la Muerte, Códice del Escorial, Madrid, Miraguano Ediciones; y Barja, J. y Calatrava, J. (eds.) (2008): Hans Holbein. La danza de la Muerte, Madrid, Abada Ediciones.

55 Becker, U. (2008): Enciclopedia de los simbolos, Barcelona, Swing, p. 296.

56 Siclier, J. (1962): op. cit., p. 150. 

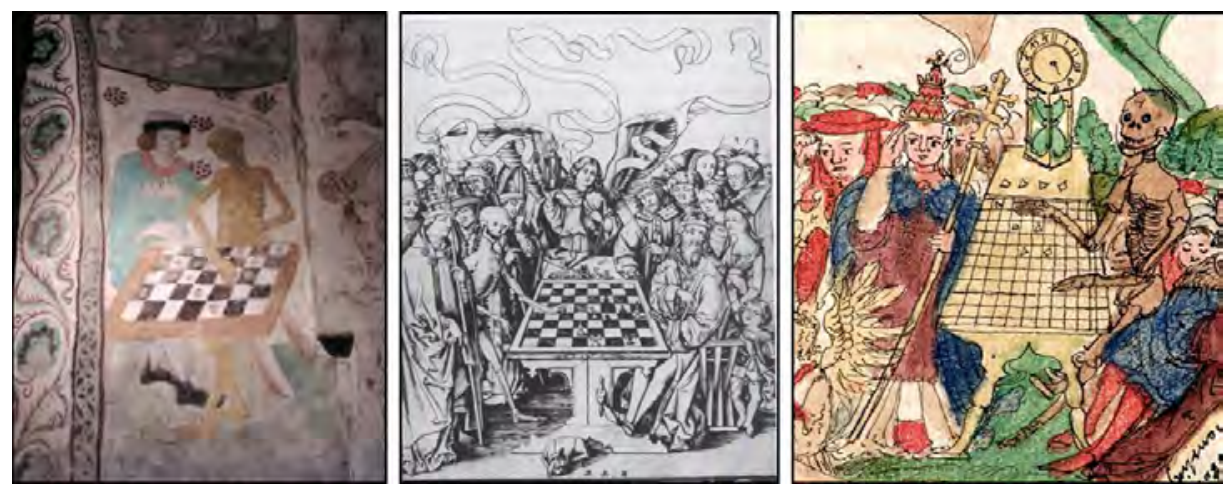

Fresco realizado por Albertus el Pintor (izquierda) e ilustraciones de origen alemán que representan la temática de La Muerte jugando al ajedrez. Siglos XV-Xvi.

Fuente: Wikimedia Commons y Stiftelsen Ingmar Bergman (http://www.ingmarbergman.se).

Muerte, quien viene a buscarlo. Antonius no quiere morir y la reta a una partida de ajedrez: si él gana, aplazarán su encuentro; y si pierde, aceptará su destino e irá con ella. La Muerte acepta ante tal ofrecimiento puesto que se considera una amante de dicho juego de mesa. Ya en época medieval se representa a la Muerte jugando al ajedrez contra un oponente cuya vida peligra. La vida es asumida como un juego, que se gana o se pierde contra la Muerte. Esta concepción simbólica es tomada por Bergman empleando dicho recurso iconográfico del ajedrez para representar simbólicamente uno de los temas fundamentales de esta película: hay que disfrutar de todos los días de nuestra vida porque nunca sabremos cuál será el último. La Muerte juega al ajedrez con nosotros y aguarda a que llegue el momento de hacerle jaque mate a nuestro rey.

Sin embargo, Bergman no emplea la cruda y medievalista imagen de la muerte, sino que la humaniza y, en cierto modo, intenta ironizarla para evitar que suscite terror. La Muerte presentada en El séptimo sello es entrañable y divertida a ojos del espectador. Esto es una respuesta al miedo que siente el cineasta hacia la concepción que tiene de la Muerte, que, dotándola de una imagen que se aproxima más a la de un personaje circense, deja de ser espeluznante e, incluso, produce simpatía. Bergman comenta en Linterna mágica (1988):

Que de repente hiciese de tripas corazón y lograse darle a la Muerte la forma de payaso blanco, un personaje que conversaba, jugaba al ajedrez y que, en realidad no tenía secretos, fue el primer paso en la victoriosa lucha contra el miedo a la muerte ${ }^{57}$.

57 Bergman, I. (1988): op. cit., p. 207. 


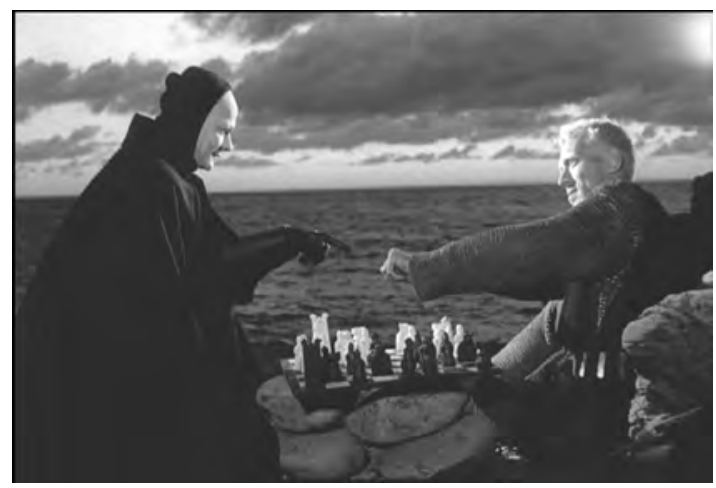

La Muerte (Bengt Ekerot) jugando al ajedrez con Antonius Block (Max von Sydow) en El séptimo sello.

Otro motivo que Bergman otorga a la idea de muerte y que es de invención propia es la denominada doble muerte. Para Bergman, la doble muerte es morir espiritualmente mientras que el cuerpo aún sigue vivo. Utiliza este motivo puntualmente en tres films, padecido por uno de los personajes, siendo su peculiar situación el motor desencadenante del resto de hechos relatados en el guion. En primer lugar, tenemos a Agnes de Gritos y susurros, cuya muerte ya está presente en los primeros minutos de la grabación. Su alma ya ha transitado, pero su cuerpo dolorido y famélico se resiste a morir. Agnes padece fuerte dolores y lo único que puede apaciguarla es la búsqueda de consuelo, negado por sus hermanas y ofrecido por su sirvienta, que la cuida como una madre. Bergman explica en Imágenes (1992) la manera en que concibe al personaje de Agnes:

Creo que la película está compuesta por este poema: una persona muere, pero se queda detenida a mitad de camino, como en una pesadilla, y pide ternura, piedad, cualquier cosa, coño. Hay allí otras dos personas [sus hermanas] y sus acciones están en relación con la muerta no-muerta [...]. La tercera [la sirvienta] la redime acunándola hasta darle sosiego, acompañándola en su camino ${ }^{58}$.

En cuanto a idea compositiva para la realización de Gritos y susurros, Bergman se basa en dos obras del pintor Edvard Munch: Muerte en la habitación del enfermo (1893) y El lecho de muerte (1893). Adapta especialmente el valor simbólico del color rojo y los colores terrosos empleados por Munch, que simbolizan al alma $\mathrm{y}$ al instintivo deseo de permanecer vivo, de existir. También es notoria la influencia de las composiciones plásticas y pictóricas del tema de la Piedad, que es imitado

58 Bergman, I. (1992): op. cit., p. 86. 

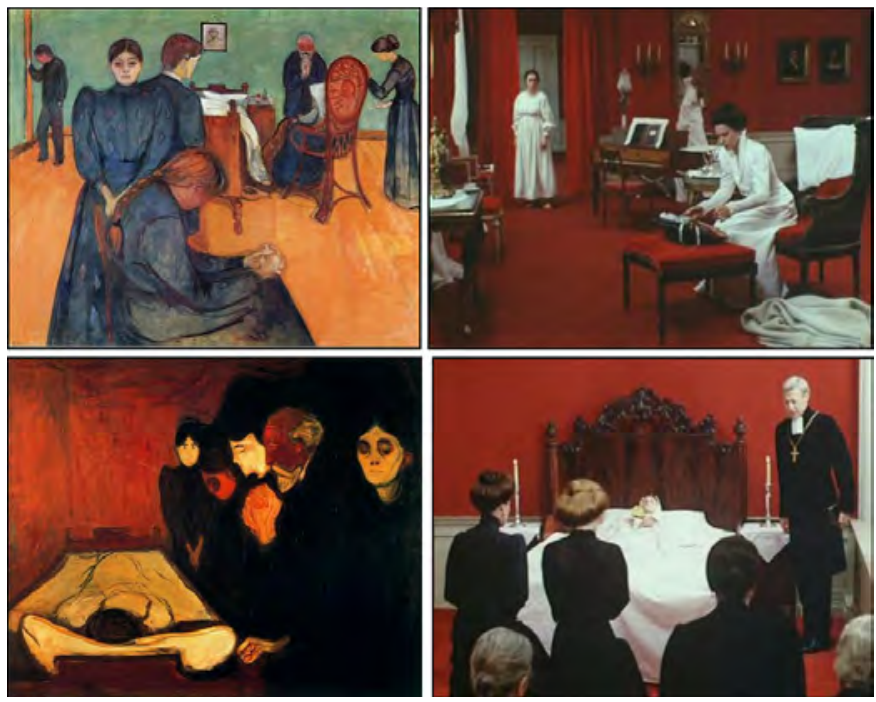

Muerte en la habitación del enfermo y El lecho de muerte, por Edvard Munch (1893), y escenas de Gritos y susurros (1972). Estas pinturas parecen haber inspirado en estética y composición al cineasta. Incluso el período histórico de estas obras coincide con el de la película.

(Fuente: Museo de Edvard Munch. Munchmuseet, Oslo, munchmuseet.no).

por Bergman en la escena de la muerte de Agnes en compañía de la sirvienta a la manera de la Virgen sosteniendo a Cristo muerto. El segundo caso es semejante al de Agnes y ocurre en el film El silencio. En verdad, el personaje de Esther que aquí se nos presenta es el precedente de Agnes: una enferma cuyo cuerpo se resiste a morir $y$, en lugar de ser guiada a la muerte por un pariente o amigo, lo hace un desconocido. En el caso de Esther, es acompañada por el amable mayordomo del hotel en el que está alojada, quien cuida de ella en sus últimos momentos. Por último, citamos al moribundo que encuentra el mago Emmanuel Vogler en El rostro. El mago acoge a un hombre después de verlo tirado en medio de un bosque. El moribundo le dice a Emmanuel que ya está muerto, pero que su cuerpo se resiste a sucumbir. Emmanuel, a pesar de ser también un completo desconocido, está con él hasta que finalmente muere.

Por último, Bergman emplea otros motivos visuales relacionados con la muerte que aparecen aislados en algunas de sus películas, pero cuyo contenido simbólico es relevante. Tenemos el columpio que aparece en Gritos y susurros, usado por las tres hermanas antes de que la enfermedad de Agnes destruya su relación. El balanceo representa «el devenir y la fragilidad de la existencia humana ${ }^{59}$ ». Por otro lado, Bergman utiliza el reloj como símbolo de Tempus fugit. La vida es un

59 Balló, J. y Bergala, A. (eds.) (2016): op. cit., p. 29. 

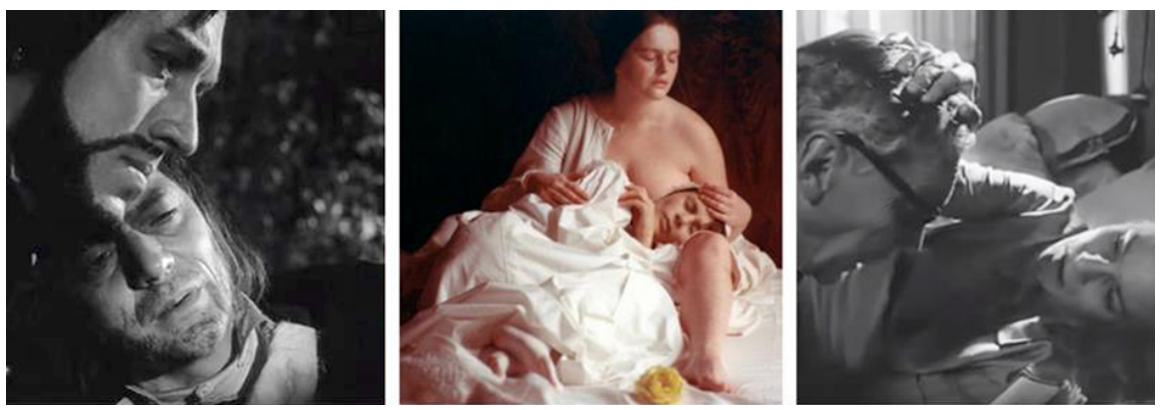

La doble muerte en El rostro (izquierda), Gritos y susurros (centro) y El silencio (derecha).

paso efímero y carece de bocetos donde ensayar previamente nuestras decisiones; el tiempo avanza y la vida es arrastrada con él. Tanto el reloj como el sonido del segundero aparecen en diferentes películas como, por ejemplo, Gritos y susurros, Fresas salvajes o El silencio. El tiempo se convierte además en metáfora de la fugacidad de la vida dentro de los diálogos de los personajes. Como diría la bella actriz Derisée cuando canta al final del film Sonrisas de una noche de verano: "Freut euch des Lebens, weil noch das Lämpchen glüht! Pflücket die Rose eh'sie verblüht!» (¡Disfruta de la vida mientras la pequeña lámpara esté encendida! ¡Escoge la rosa antes de que se marchite!).

\section{CONCLUSIONES}

A lo largo de este artículo, hemos podido conocer los motivos visuales más representativos en el cine de Ingmar Bergman y cómo estos ahondan en concepciones simbólicas universales, así como aquellos que él mismo elabora y reinterpreta a fin de manifestar sus propios pensamientos y experiencias de vida. Asimismo, pudimos analizar a partir de estos motivos aquellos temas que definen la obra del autor, destacando el amor, el sexo, la incomunicación, la concepción muy adelantada para su tiempo que tenía de la mujer moderna y de las relaciones amorosas, la profunda huella que dejan las apariencias en las personas, la muerte y la duda acerca de la existencia de Dios. En este sentido, observamos que su cine toca el aspecto social, pero se centra especialmente en problemas metafísicos y existenciales, así como en la infelicidad. Bergman también representa a la Europa de su tiempo tal y como es. En su filmografía vemos la crítica que hace de la sociedad posmoderna, que es cada vez más vacía, apegada al consumismo, y a las dificultades que tiene para comunicarse entre sí.

En cuanto a los motivos visuales analizados, recordemos que los presentados en este artículo no son ni de lejos todos los que el cineasta emplea, pero sí se pueden considerar estos como los más representativos y utilizados. Por ejemplo, también sería relevante el estudio de otros motivos visuales aquí no mencionados, 
tales como la máscara, el artista, el padre, la madre o el mar. Por otro lado, podemos contabilizar un mayor uso de motivos visuales en la primera etapa cinematográfica anterior a las dos trilogías. A partir de Crisis (1944) hasta El manantial de la doncella (Jungfrujällan, 1960) observamos un despliegue diverso de motivos visuales. Desde comienzos de su carrera como cineasta, Bergman emplea los motivos que definirán su estilo, destacando especialmente el motivo del espejo. A partir de Como un espejo (1961), película con la que se inicia su primera trilogía, hasta Saraband (2003), los motivos visuales son más escasos y están relacionados con la problemática sobre Dios, pero cuentan con un mayor peso. Dependiendo del tema que trate la película, Bergman optará por unos en concreto y descartará otros. A partir de los años setenta, Bergman retoma de nuevo su interés por las relaciones interpersonales como ocurrió a inicios de su carrera, aunque en esta ocasión se enfoca en aquellos motivos visuales vinculados con el erotismo, como la cama o el desnudo. Del mismo modo, Bergman volverá a otorgar relevancia al motivo del espejo. En el film Fanny y Alexander (1982) observamos un despliegue cinematográfico impresionante. Bergman deja aquí todo lo que podía ofrecerle al cine, haciendo uso de gran parte de los motivos visuales que definen su sello artístico.

Si bien es cierto que la obra de Bergman es compleja, se deja leer claramente cuando se conoce tanto su biografía como el significado que encierran los motivos visuales que emplea como recursos narrativos. Sin ninguna de estas dos premisas, sería una tarea casi imposible entender su obra; ambas son la llave que abre el universo cinematográfico de Bergman, sus temas y su estilo. En cuanto a experiencia personal, ya sentía fascinación por las películas del director sueco antes de poder estudiarlas en la universidad; sin embargo, distaba de poder entenderlas. Las veía como imágenes encriptadas en un lenguaje tan complejo que escapaba a mi entendimiento y en donde únicamente era capaz de captar su sutileza estética y fuerte carga emocional. Por tanto, es tarea imprescindible leerse sus autobiografías como paso previo a la visualización de sus películas y así poder desentrañar ese lenguaje escondido tras el lirismo de sus imágenes y que, junto con el estudio de sus motivos visuales, se consigue como resultado de un análisis más detallado.

En definitiva, conocer a Bergman es conocer su filmografía. Conocemos sus cualidades prodigiosas en la forma con que elabora sus guiones y la fuerte carga intelectual que utiliza en ellos; conocemos su amor por el teatro, al que tanto debemos, pues fue fuente de inspiración para su cine; conocemos a sus actores, a los que dirige frecuentemente en sus películas; conocemos a su familia y, por ende, su triste infancia y atormentada juventud. Pero no llegaremos a conocerle si lo reducimos a fórmulas vacías, a imágenes que solo buscan la provocación y la irreverencia, porque en ese caso estaríamos cometiendo un grave error.

El cine de Ingmar Bergman celebra, sobre todo, la vida en todas las facetas que la podamos experimentar, tanto negativas como positivas. Es una reflexión sincera acerca de lo que verdaderamente nos hace humanos. 


\section{FILMOGRAFÍA DE BERGMAN EMPLEADA PARA EL PRESENTE ARTÍCULO}

\section{(POR ORDEN CRONOLÓGICO DE PRODUCCIÓN)}

- Crisis (Kris, 1946).

- Llueve sobre nuestro amor (Det regnar pavar kärlek, 1946).

- Barco hacia la India (Skepp till Indialand, 1947).

- Música en la oscuridad (Mosik i mörker, 1948).

- Prisión (Fängelse, 1949).

- La sed (Törst, 1949).

- Tres mujeres (Kvinnorväntan, 1952).

- Un verano con Mónica (Sommaren med Monika, 1953).

- Noche de circo (Gycklarnas afton, 1953).

- Sonrisas de una noche de verano (Sommarnattens leende, 1955).

- El séptimo sello (Det sjunde inseglet, 1957).

- Fresas salvajes (Smultronstället, 1957).

- El rostro (Nära Livet, 1958).

- El manantial de la doncella (Jungfrukällan, 1960).

- Como en un espejo (Sasom i en spegel, 1961).

- Los comulgantes (Nattvardsgästerna, 1963).

- El silencio (Tystnaden, 1963).

- Persona (Persona, 1965).

- La hora del lobo (Vargtimmen, 1968).

- El rito (Ritten, 1969).

- La carcoma (Beröringen, 1971).

- Gritos y susurros (Viskningar och rop, 1973).

- Secretos de un matrimonio (Scener ur ett äktenskap, 1973).

- El huevo de la serpiente (Das Schlangenei, 1977).

- De la vida de las marionetas (Aus dem Lebem der Marionetten, 1980).

- Fanny y Alexander (Fanny och Alexander, 1982).

- Saraband (Sarabande, 2003).

\section{Otros FILMS CONSULTADOS}

- Las ciervas (Les biches, Claude Chabrol, 1968).

- Mulholland Drive (David Lynch, 2001).

- Tres mujeres (Three Women, Robert Altman, 1977).

- Noche de estreno (Opening Night, John Cassavettes, 1977). 
